Book Reviews, Relegere: Studies in Religion and Reception 3, no. I (2013): I6I-2 I9.

(cc) BY-NC-ND This work is licensed under a Creative Commons Attribution Non-Commercial No Derivatives 3.0 License.

Relegere: Studies in Religion and Reception is an independent, open-access academic journal dedicated to the promotion and dissemination of innovative research in reception history, broadly conceived, within and across religious traditions.

www.relegere.org

ISSN I I 79-723 I 


\section{Book Reviews}

George Aichele

The End Will Be Graphic: Apocalyptic in Comic Books and Graphic Novels, edited by Dan W. Clanton . . . . . . . . . . . I6I

Stephanie L. Derrick

The I Ching: A Biography, by Richard J. Smith . . . . . . . . I65

Bryan S. Turner

Miracles of Book and Body: Buddhist Textual Culture and Medieval Japan, by Charlotte Eubanks . . . . . . . . . . . . . . . 168

Yael Klangwisan

Yearning for You: Psalms and the Song of Songs in Conversation with Rock and Worship Songs, by William Goodman . . . . . . . . I73

William John Lyons

Sex, Wives, and Warriors: Reading Biblical Narrative with its Ancient Audience, by Philip F. Esler . . . . . . . . . . . . 176

Gustavo Riva

The Practice of the Bible in the Middle Ages: Production, Reception and Performance in Western Christianity, edited by Susan Boynton and Diane J. Reilly . . . . . . . . . . . . I 82

Deirdre Good

Shakespeare, the Bible, and the Form of the Book: Contested Scriptures, edited by Travis DeCook and Alan Galey . . . . . . . . . . I87 
Carol A. Newsom

Breaking Boundaries: Female Biblical Interpreters Who Challenged the

Status Quo, edited by Nancy Calvert-Koyzis and Heather Weir . . 190

Peter Lineham

Recruiting Young Love: How Christians Talk about Homosexuality, by

Mark D. Jordan . . . . . . . . . . . . . . . . . . 194

Ibrahim Abraham

The Juvenilization of American Christianity, by Thomas E. Bergler . 196

Brandon W. Hawk

Anthems of Apocalypse: Popular Music and Apocalyptic Thought, edited by Christopher Partridge . . . . . . . . . . . . . 200

Mike Grimshaw

New Zealand Jesus: Social and Religious Transformations of an Image, I890-1940, by Geoffrey Troughton . . . . . . . . . . . . 204

Davina C. Lopez and Todd Penner

Jesus in an Age of Neoliberalism: Quests, Scholarship and Ideology, by James G. Crossley . . . . . . . . . . . . . . . . . . . . 207

Peter Lineham

Dreaming of Eden: American Religion and Politics in a Wired World,

by Susan Brooks Thistlethwaite . . . . . . . . . . . 2 I4

Peter Lineham

The Book of Mormon: A Biography, by Paul C. Gutjahr . . . . . . . 216 


\section{The End Will Be Graphic: Apocalyptic in Comic Books and Graphic Novels, edited by Dan W. Clanton}

The Bible in the Modern World 43 | Apocalypse and Popular Culture 5 | Sheffield: Sheffield Phoenix Press, 20I 2 | xix + I I4 pages | ISBN: 978-I-907534-49-2 (hardback) $£ 45.00$

The field of Bible and popular culture is one of the fastest growing areas of biblical studies today, as can readily be determined by looking at the programs of scholarly conferences and the new listings of publishers in that field. Although scholars have been studying relations between novels, films, or TV shows and biblical or other scriptural texts for some time now, attention has recently turned also to other categories of popular culture, and "comic books and graphic novels" is one of those categories. The scholarly writings of Dan Clanton have been at the forefront of such innovative studies.

The End Will Be Graphic, edited by Clanton, brings together seven contributors from the fields of religious and biblical studies, English literature, graphic arts, and popular culture studies. Following Clanton's helpful and substantial introduction, the book is divided into two parts: "Independent and/or Creator-Owned Comic Books and Graphic Novels" and "Mainstream Comic Books and Graphic Novels." Part I consists of Aaron Kashtan, "A Network of Lines that Intersect: Apocalyptic Imagery and Comics Form in Kevin Huizenga’s 'Jeepers Jacobs'"; Emily Laycock, "Graphic Apocalypse and the Wizard of Grotesque: Basil Wolverton, the Worldwide Church of God, and Prophecy"; Diana Green, "The World of the End As We Know It: Alan Moore's Deconstruction and Reconstruction of Apocalyptic Concepts in Promethea"; and A. David Lewis, "(Ir)reverence After Rapture: Mocking and Maintaining Christian Doctrine in Battle Pope, Chronicles of Wormwood and Therefore, Repent!" Part 2 consists of Terry Ray Clark, "Apocalypse Then and Now: Kingdom Come and the Tradition of Imagining Armageddon"; Gregory Stevenson, "Of Beasts and Men: The Book of Revelation and the Apocalyptic Superhero”; and Greg Garrett, "Now the Whole World Stands on the Brink': Apocalypse and Eschatological Hope in Contemporary Superhero Comics." Each entry is followed by its own bibliography; a combined volume bibliography would have been more helpful. In addition, the book includes indexes of biblical citations and of names. 
Although the essays often speak of religion in general, the book's focus is almost entirely on contemporary forms of Christianity. All of the graphic apocalypses mentioned in Clanton's book are more-or-less Christian in orientation, even when their thrust is anti-Christian. For example, Green begins by talking about a "journey through all major faiths" (35), but the reader of her essay is taken on a journey from the Tarot by way of Teilhard (whom she calls "de Chardin"), noogenesis, and physics to Gnosticism. Later Green mentions "gods from a gamut of faiths" (4I), but these gods all praise the crucified Christ. The death of Promethea's pagan father at the hands of Christians is treated as "bias against the Christian ethos"; evidently Green is unfamiliar with the story of Hypatia.

Even the Superman stories are discussed in relation to Christian texts. However, a quick visit to the "Religious Affiliation of Comic Book Characters" webpage (http://www.adherents.com/lit/comics/comic_book_religion. html) reveals an impressively wide range of religious options in comic book stories. To be sure, those heroes are probably not all involved in apocalyptic stories, but if there truly were no non-Christian apocalyptic comics, then that lack would itself be an important topic for discussion. As it is, surely some apocalyptic comics or graphic novels reflect Jewish, Hindu, or Muslim beliefs, or tell stories and describe worlds more on the order of (for example) China Miéville's non-graphic novel, Kraken (2010), in which Revelation's apocalypse is at best just one of many revelations (and not the most pressing). If the book's contributors are only interested in discussing Christianity, then that should have been more clearly indicated.

Furthermore, this is not a book about the Bible, and although Revelation is by far the most often cited biblical text (out-numbering all other biblical citations combined), this is not a book about the Apocalypse of John. There is very little serious engagement with any biblical text, and no biblical scholars, apart from John and Adele Yarbro Collins, are cited more than once. This is not an objection to the Collinses, but this lack of more wide-ranging reference to biblical scholarship reinforces the mistaken idea suggested in several of the essays that "apocalyptic," as concept or as genre, is undisputed. Garrett even claims, citing John Gray, that Western apocalyptic traditions derive from "Jesus and his followers" (IOO-I). Only twice is it briefly noted (by Green, 38, and Stevenson, 82) that "apocalypse" is not equivalent to "story about the end."

Similarly, the Apocalypse of John is generally presented throughout this collection as though its meaning is undisputed, either by scholars or among readers in general, and the only disagreement that is noted (by Garrett, IOI) 
concerns the value of its symbolisms. Instead, the general understanding seems to be that the "themes or characters [of 'the biblical text itself'] are 'mediated' through later interpretations" (Clanton, xiii), and the contemporary graphic stories are treated as though they are exegeses of a univocal biblical text. (Correspondingly, but on the other side of the coin, Stevenson describes Spawn: The Armageddon Collection as "decidedly unbiblical," 87.) The fact that the old stories have been resurrected in so many different afterlives apparently says nothing to these contributors about the polysemy of those stories.

The book's articles nicely demonstrate in a variety of ways how many traditional apocalyptic themes are played out, often in quite non-traditional ways, in modern comics and graphic novels. However, although these comics are often critical of the Bible, and they mock or parody traditional beliefs, texts, and images, the essays in the book acknowledge no point at which the biblical texts critique the graphic stories. Even whether or how the mockery or parody does anything more than simply deface the traditions, like drawing a moustache on the Mona Lisa, is not always clear. Only in the essays by Lewis and Clark is there any sense of tension between the modern rewritings of the old stories and the old stories themselves, or of differences that might imply important things about both the new and the old.

Clanton and various contributors note that biblical apocalypse has been "secularized" in these comics and graphic novels. This implies that the biblical texts are "religious," and Garrett even devotes several pages to the matter. Despite this, the distinction is never justified. Instead, it seems arguable to me that Revelation is already "secular" (as are other apocalyptic materials in the Bible, such as the flood story in Genesis), as the story occurs primarily in this world, not in the realm of the gods. The biblical apocalypses may even call for ongoing secularizations (reading Revelation 22:1 8-19 as a challenge, a taunt). Indeed, what makes any story "religious," except for the fact that many people already read that story as having religious significance? Surely no visual or verbal feature of "the text itself" could signify this difference. For example, are Wolverton's Revelation images secular (as Laycock says, 28) or, as part of The Wolverton Bible, have they become religious? Laycock's essay might have investigated such religious-secular transformations, but instead she spends many pages detailing the careers of Wolverton and Herbert Armstrong, and only a few pages on the images themselves.

Despite the negative tone of some of these remarks, I admire this book, and I regard it as a positive addition to the field. Study of biblical texts in relation to comic books or graphic novels is still a relatively new thing, and 
the first efforts will be awkward at times. Nevertheless, Kashtan in particular does a fine job of exploring the material verbal/visual "mediation" offered by these cartoon books, and he is joined in this concern by Clanton, Laycock, Lewis, and Clark. Mediation is never transparent, and interference (Michel Serres's "parasite," I982) is inevitable. In this regard, comics and graphic novels have features in common with film (especially animated film), with its continuous sequence of frames. However, important differences remain. Like the reader of any written text, including the Bible, the reader of the comic book can pause or flip back and forth at will without seriously disrupting the experience. She can even put the book down and do something else for a while before picking it up again where she left off. A film-even a film recording — is more all-consuming, more demanding of its viewer's attention.

The seemingly inherent seriality of comic books is another important feature and is also noted by several of the book's contributors (especially Lewis). Comics and graphic novels share this quality in particular with TV series, and it stands in profound tension with any eschatology, apocalyptic or otherwise. The story "wants" to go on. A third feature of comic books (this one not touched upon in Clanton's book) is their deep roots in "pulp literature"cheaply-made, easily recycled-which they share with dime novels, tracts, pamphlets, and perhaps even the earliest gospels. One wonders if the more recent development of the graphic novel, often printed on glossy paper and often more expensive than the traditional comic book, is not an attempt to escape from these roots, to become more serious and noteworthy.

I recommend this book, not because it thoroughly addresses all of the important questions, but because it is very good at provoking some of those questions, and at showing valuable directions for further study.

George Aichele Adrian College (retired) 


\section{The I Ching: A Biography, by Richard J. Smith}

Lives of Great Religious Books | Princeton: Princeton University Press, 2012 |xxii + 278 pages | ISBN: 978-0-69I-I 4509-9 (hardback) $\$ 24.95$

For most Western non-specialist readers, an introduction to the life of the I Ching (also called the Yijing and the Changes) will have its challenges. It is a text like no other within the world's major religions. At

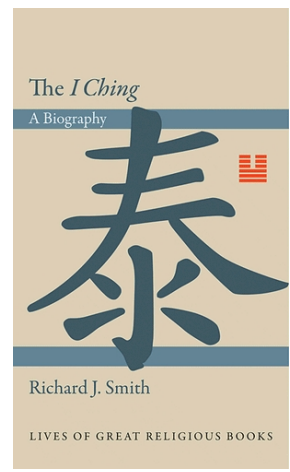
its core are sixty-four seemingly simple images, each constructed of six lines, which have collectively been understood by the most brilliant minds of China for well over two thousand years to represent perfectly the nature of reality, to reveal the past and future, and to provide a surefooted guide to right behavior. The Changes has no narrative, no gods to speak of, and by its very nature encourages a multiplicity of interpretations. Perhaps the most difficult leap for the initiate to this Chinese classic is that abstract pictures, not words, are at the heart of the meaning-making process.

These fundamental differences between the Changes and other major religious books are what make Richard J. Smith's biography (one in a new series from Princeton University Press about the reception of classic religious texts) such an excellent guide. If one cannot, at first, make heads or tails of what, exactly, has captivated the imaginative, intellectual and spiritual lives of so many people - if the allure of the images is unintuitive-one may at least appreciate seeing the book in action, as it evolved over time. Smith takes his readers through the Changes's life, from its elusive origins as one of many divination manuals, to a text with state-sanctioned commentaries and Confucian affiliations, to its destiny as an undisputed authority for Chinese life and thought at all levels of society. Not only that, Smith considers the Changes's presence in non-Chinese contexts, contrasting the book's life in its home country with that of its adoptive cultures in Korea, Japan, Vietnam, and the West. An appreciation of the book's cultural importance grows as Smith transitions through so many successive periods and circumstances. To be privy to a bird's eye view of the history of the text (accomplished in under 250 pages) is to have glimpsed the sheer scale of human energy spent on its meaning and powers; it is to be persuaded of Smith's argument that the Changes has had such influence on account of "the intellectual challenges it 
poses, the psychological insights it encourages, and the creative inspiration it affords" (2I 2).

Smith's biography is an excellent example of the clarity that may be lent by book history and reception methodologies. The key, I think, in Smith's case, is his having struck the right balance between metaphysical and historical interests and examples, as he moves through his chronology. For example, by succinctly charting the schools of thought that developed in Early Imperial China, and their various readings of the Changes, one is helped to understand not only how the text met the intellectual and philosophical needs of the period but the historical circumstances themselves. Repeatedly, textual interpretation illuminates a particular moment in Chinese (or Japanese or Korean) history; and by tracing interpretive changes one absorbs more fully, along the way, the nature and fundamental appeal of the text. Balancing the historical and metaphysical, and the changing and the unchanging, attributes of this text's reception is a particularly apt quality in Smith's presentation because the Changes itself seems equally Earth-bound-a guide for the most mundane of life's affairs-and quintessentially esoteric. Also satisfying to the historian, Smith at all moments seems to be in control not only of the enormous amount of commentary on the Changes but also of the most salient national, cultural, and philosophical circumstances impinging on the life of this text, from contact with new, "foreign" Buddhist ideas to the rise of emphasis on textual criticism in Korea. Moreover, he manages to consistently clue the reader into the distinctions between popular and more scholarly receptions, be alert to the physical environment, and bring colorful personalities into the narrative, where illustrative.

The section of the book that considers the Western reception of the Changes is the one to which the most outside knowledge is brought to bear by the present reviewer. Smith does two things very well on this point. First, he spends substantial time on fascinating, if somewhat obscure, pre-twentiethcentury investigations by Westerners of the Changes. The attempt of the French Jesuit Joachim Bouvet to reconcile a Christian cosmology with the text and the effort of the British Protestant missionary Joseph Edkins to simply understand the wisdom of another people are well worth the pages spent on them; furthermore, these cross-religious case-studies vanquish what will be a preconception among many: that the Beat Generation were the first to appropriate from the East. Secondly, Smith does well also to highlight the fact that it was not only in America that the counter-cultural movement of the I 960 os looked to East Asian religious traditions for creative, personal, cul- 
tural, and political inspiration. Indeed, the author points to many artists and writers in Mexico, for example, including Octavio Paz, Salvador Elizondo, and Francisco Serrano, for whom the Changes was important.

That said, it is slightly disappointing that there is little in the way of an explanation as to why the Changes has appealed to post-1950s Western culture. And to the extent to which an explanation is offered, there is the possibility, at least, of a contradiction. On the one hand, Smith speculates that the popular appeal "can be explained primarily by the challenge the book seems to pose to conventional Western values" (194). Yet if, as he says, the influence has been "substantial and persistent" since the I960s, to the extent that English translations and symbols from the Changes have become successfully commercialized (as he mentions), then there must be something at stake for people not quite aligned with the counter-cultural artists given attention in this section-Bob Dylan, Allen Ginsberg, the novelist Philip K. Dick, and the like. If there was a successful move to the commercial mainstream, then there must be something about the book that appeals to a wider sector of society than discussion of this sub-culture would suggest. Smith alludes to this fact in his critique of another scholar's article, saying "one did not have to be a hippie to explore and experiment; 'straights' discovered that they could also join the fun." However, Smith himself hardly goes beyond the cliché. Moreover, Smith mentions that this commercialization "has increased steadily, and sometimes dramatically, in recent years," which holds out the possibility that, actually, there just may be some phenomenon, some cultural development of the I990s, for example, that has more pertinence to the discussion of the Changes's history in the West than do the heady days of Flower Power.

Small, singular criticism aside, Smith's biography does what an introduction should do: encourage the reader to want to know more and provide a smooth over-arching conceptual framework, in economic fashion, through which one may understand the details. It would, therefore, be a helpful tool in a university course on Eastern or World religions and is highly recommended.

Stephanie L. Derrick University of Stirling 


\section{Miracles of Book and Body: Buddhist Textual Culture and Medieval Japan, by Charlotte Eu- banks}

Berkeley and Los Angeles: University of California Press, 20I I |xviii + 269 pages | ISBN: 978-0-520-2656I-5 (hardback) $\$ 55.00$

Charlotte Eubanks's elegantly written study of mate-

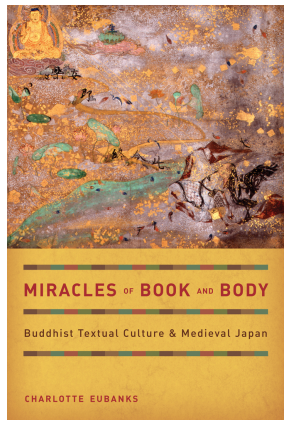
riality and textuality is an inquiry into Buddhist textual culture and religious practice, primarily of Mahāyāna Buddhism in medieval Japan. More specifically, she offers an analysis of setsuwa or the explanatory notes that often accompanied sermons to illustrate doctrine. The setsuwa typically employed popular stories about the Buddha and his followers as a method of expanding on the dharma. These were compiled into various literary collections between the ninth and thirteen centuries in Japan and thus they span the period when Buddhism expanded beyond the court into every level of Japanese society. The first significant Buddhist collection ( $A$ Wondrous Record of Immediate Karmic Retribution) was put together in the 820 and the final collection (Collection of Sand and Pebbles) was completed in the 1280 . These collections correspond to the Heian (794-I I 85 ) and Kamakura (I I 8 5-I 333 ) periods. In this era, which for convenience she calls "medieval," the advent of Buddhism coincided with the introduction of a written script from China, and produced an aesthetics that was distinctively Buddhist. While much of the material in the setsuwa had its origin in oral narrative, the Japanese genre of these explanatory tales was influenced by both Indian and Chinese narrative forms. Of special note were the Indian "karmic biography" and birth tales, and Chinese miracle stories.

These setsuwa collections emerged out of centres of aristocratic culture in or near the imperial city of Heiankyo (or modern day Kyoto) and, although their main characters came from a wide variety of social classes and status groups, these narratives reflect the habitus of the nobility and hence the premium that their life style placed on personal cultivation and cultural sophistication. However these narratives also recognized the emotional volatility of amorous relationships and the violence that inescapably attends politics. The collections were composed by three authorial categories: the laity, 
clerics writing for professional purposes, and individuals either writing for themselves or for a specific individual. The latter texts are deeply poetic and personal with ample use of allusion and metaphor.

Concentrating on nine collections of setsuwa that serve as the basis of her study, she examines them alongside the canonical sutra texts, demonstrating how these popular stories unite text and audience into a "textual community" in which setsuwa and sutras intersect. Her account of the centrality of this literature to Mahāyāna Buddhism depends to some degree on Gregory Schopen's Figments and Fragments of Mahāyanna Buddhism in India: More Collected Papers (Honolulu: University of Hawai'i Press, 2005) in which he coined the phrase "the cult of the book." Eubanks comments that "the Mahāyāna distinguished itself by establishing cultic centers organized not around stupas, but rather around written sutra texts that were recited, worshipped, honored, and circumambulated" (2I).

Eubanks sets herself three questions for which this publication seeks to provide answers. The first question is about ontology - where does text exist? The second question is sociological- how can we understand text not (only) as a material "thing" but (also) as material "event"? The final question is historical—what do Buddhist books look like? Who created them where, when and how? We might suggest that a single answer to these valuable questions is that Buddhist scriptures came alive through embodied performances that created communities that became the vehicles for the maintenance and transmission of the dharma.

To open this review, we might take the three nouns that form the title of her book. First, and following the work of Caroline Walker Bynum on miracles and the theology of redemption in medieval Europe (Fragmentation and Redemption: Essays on Gender and the Human Body in Medieval Religion [New York: Zone Books, I 992]), Eubanks observes that, while miracles are unexpected and unpredictable, there are methods-prayer, fasting, selfmutilation, and sleep deprivation — by which they may be courted. Similar religious methodologies were embraced in Japan, where wakefulness, prayer, pilgrimage, and training of the memory were practices by which the devotee might receive a miraculous sign. Secondly, she offers a close study of the setsuwa as literature in which she excavates "some of the symbols and structures through which sutras build themselves into narratives of meaning, paying special attention to the metacommentary that sutras offer about how they should be read and about the place of reading vis-à-vis other methods of 
textual engagement, such as recitation and circumambulation" (13). Thirdly this study is a sustained analysis of how the human body is connected with the body of the text. Eubanks proposes that the body and sutras are comparable, namely they are exemplary sites where the core themes of Buddhist teaching on suffering and impermanence can be strikingly encountered. We need here to comment briefly on the idea of body. The human body is a special type of container for Buddha's teaching and is referred to as the "dharma vessel." More precisely, the human body is "the embodied sense organ of the mind" ( 56$)$.

There are two important themes that are established in the Introduction and Chapter I on "The Ontology of Sutras." The first theme is the relationship between the textual and the oral, and between the text and the work. The setsuwa and sutras were written on scrolls of various sorts but they were also to be read and recited, and hence they depended on performance. Literature as a result exists at two interconnected places, namely on the printed page and in the minds of a social community of readers and writers. In the field of textual studies, it is consequently important to make a distinction between the text and the work. The latter is an assemblage of pieces of literature that can be expressed in the various forms (in folio, quarto, in vellum, or in a great variety of editions) but it cannot be reduced to any single one of these expressions. Furthermore the linguistic text can be housed in any number of material forms of physical containers. The linguistic text and the physical container is the "material text," and this text is available to the human senses. In reference to Buddhist literature, the sutra as a linguistic text (a string of words and line breaks) is an abstraction that survives by situating itself in a container such as popular memory or on an external surface of leaves or paper, but these are perishable. However the sutra as work continues to live as an abiding teaching in the dharma. Writing and memory were simply two techniques for storing a text. As places for storage, both were subject to damage, decay, and erasure. The work itself by contrast was eternal and sacred.

There are in fact three classical means of storage. These are the stupa-ascontainer, the scroll-as-container, and the mind-as-container. This discussion of how the dharma is to be held and transmitted brings us to what I regard as the second dominant theme of Eubanks's study, namely the vulnerability of things, texts, and bodies. Buddha and his disciples were constantly aware that the dharma might be lost, destroyed, or corrupted. How could its trans- 
mission over time be guaranteed against both external and internal threats? Stupas can be destroyed, scrolls can be corrupted, and memories can fade. Memory is unreliable and the body is frail and subject to decomposition. Indeed contemplation of a rotting human corpse is an established component of Buddhist monastic training. The Buddhist aspirant would visit a charnel house in order to gaze upon the full horror of decomposition and degradation. Various setsuwa describe how a lay person, suddenly confronted by a dead and decaying body is moved to follow the Buddhist path.

One response to this dilemma of vulnerability was to emphasise the importance of discipline and training in the memorization and recitation of texts. Eubank approaches this issue through a discussion of the idea of accepting and holding onto the sutras. The idea of holding onto the teaching has two components- the one who accepts and holds, and that which is accepted and held. While monks and laity may aspire to perfect memory, the power of total recall belongs only to buddhas and the most advanced bodhisattvas. The Flower Ornament Sutra asserts that the core quality of buddhas is that they are able to accept and hold on to all Buddha dharmas. For bodhisattvas the cultivation of free and unhindered access to the dharma comes only after endless lifetimes of discipline in which they start with text and conclude with the work or dharma. The devotee Sudhana was able to move from cataloguing individual sermons to accessing the complete dharma library. Memorizing the teaching had thus transformed him into a storehouse of the dharma.

The Mahāyāna vocabulary often had an erotic dimension in that the sutras live within the body of believers who are dharma vessels in providing shelter and protection. In return the sutras can have miraculous effects in giving relief from illness and promoting longevity. There is an exchange relationship or symbiosis between the gift of the dharma and the activities of humans. Human bodies can break down into textual fragments and textual fragments can become embodied in humans. In this symbiotic relationship, the humans become womb-like containers into which the seed of the teaching is inserted. From these metaphors, we can learn that Mahāyāna Buddhism understood paper (or other writing surfaces such as leaves or silk) and the human body as simply material locations for the inscription of sacred texts. The setsuwa were self-reflexive in their approach to somaticity, materiality, and ontology in which the text-flesh relationship was paramount within the narratives. While these erotic metaphors were common, the setsuwa texts 
were also conceived as a type of food or medicine which had to be ingested. The purpose of the text was to nourish and sustain mind and body, bringing about a religious awakening and growth.

Charlotte Eubanks's Miracles of Book and Body is a major contribution to the study of Japanese setsuwa as literature and, bringing her literary-critical skills to bear on these texts, she has fully excavated the wealth of narrative techniques that were skilfully deployed to hold an audience and thereby to transmit the work as dharma. However, this captivating study can also be understood more comprehensively as a contribution to the contemporary interest in the human body ("the turn to the body"), performance, popular culture, and material cultures. Contemporary scholarship in both anthropology and sociology has been critical of the narrow focus in traditional scholarship on religious belief and the corresponding neglect of practice, performance, and ritual. This conventional focus on religion as belief has been attributed to the legacy of Protestantism on religious studies. Eubanks, drawing attention to the performance of setsuwa in the context of Buddhist gatherings to hear sermons, recognises the historical value of Notes on One Hundred Sessions of Sermons, which tells of the network of clerics around the early i Ioos who were identified as talented preachers. These men could be engaged to provide sermons at Buddhist ceremonies that might involve the dedication of a sutra. These narratives give us an insight into the liturgical performance of the ceremonies, the organization of such meetings, the role of local patrons of Buddhist sites and services, and the norms that emerged to determine the order of events. Beginning in the late twelfth century, there were attempts to standardise these norms, which had evolved for the practice of sermons, in order to define their protocols, etiquette, and sequencing. These Notes offer an important insight into actual performance and practice.

Miracles of Book and Body begins with the account of medieval Buddhism with the story of Myoe (I I73-I 232) a monk who decided that a shaved head was no longer sufficient evidence of a person's devotion or true intentions. Seizing a knife, he sawed off his right ear, splattering blood over the ritual implements before him. What was the logic of this pious act? This removal of an ear dramatically defined the physical correlation between text and body. By removing an ear rather than an eye, a hand or a nose, he was still able to see, hold, and hear the sutras. Eubanks returns to this story towards the conclusion of her book to demonstrate the constitutive importance of the text-flesh continuum in Buddhism. Chanting, copying, memorizing, and preaching are religious activities that are aspects of this continuum. The voice that is 
necessary for chanting and the hand that is necessary for copying the scriptures have profound significance; they contain "the presence and the body of the Buddha” (I72). In these devotional performances, miracles, books, and bodies finally come together in a shared ontology.

\author{
Bryan S. Turner \\ The Graduate Center \\ The City University of New York
}

\title{
Yearning for You: Psalms and the Song of Songs in Conversation with Rock and Worship Songs, by William Goodman
}

Sheffield: Sheffield Phoenix Press, 2012 | xii +267 pages | ISBN: 978-0-8028-6684-4 (hardback) £60.00

William Goodman-inspired by Leonard Cohen's anthem to love, "From your lips she drew the Hallelujah"-explores the connection between the

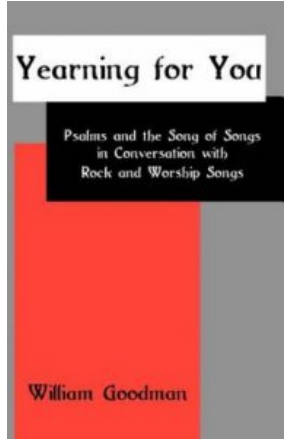
erotic and the religious in both secular and Christian contemporary music.

Goodman's first task is to provide evidence that religious language is rife in popular music and "romantic" language in Christian music. He sees this connection as a kind of blurring of boundaries between desire for God and sexual desire. Furthermore, Goodman wants to explore song texts in scripture and draw these together with a set of relevant samples from contemporary music. Psalms and Song of Songs are his biblical touchstones and his next moves are to inventory and to analyze the interpretive writings of various historical commentators of these two biblical books, focusing on "themes of desire and intimacy" (69). Goodman engages both Christian and Jewish traditions of interpretation of Psalms and the Song, albeit briefly. This is an accessible chapter where Goodman admirably traces the ebb and flow of exegetical opinion over centuries of biblical engagement in less than fifty pages.

Goodman's comparison and contrast of the Psalms and Song of Songs in "My God ... My Beloved" (chapter 3) is rewarding. Goodman gives a strong summary of various relational themes such as desire, absence, longing, feasting, and so on before moving on to consider samples from the contemporary music scene. 
In Goodman's final and most significant chapter he presents several explanations for the religious-romantic language connection in the Psalms, Song of Songs, and selected contemporary music. He considers both the possibility that behind such language is the notion that sex is a means to experience the divine, and that sex might be conceived as sacrament for the divine. He discounts both of these in favour of a careful notion of sex as a metaphor for the divine. This outcome was perhaps a fait accompli, set up from the prelude, which introduces the book via recourse to Dan Brown's The Da Vinci Code, hieros gamos, and the Song of Songs. Rather transparently, Goodman presents this provocative mechanistic or shamanistic conception of the erotic-divine relation as a straw man that he will dismantle in this concluding chapter. While the point Goodman is making is entirely valid, he has gone about it in a slightly disingenuous way. Metaphor is the obvious conclusion given that a text-based poetic analysis of any kind will inherently involve metaphor as a central concern as opposed to Goodman's two discounted presentations which are embedded in actual physicality and practice (2OI-2). For the fleshing out of Goodman's preferred explanation he wisely goes to Ricoeur and Ricoeur's notions of the living metaphor.

Goodman extends the investigation by postulating a series of metaphors for the human-divine relation relevant to the Psalms, the Song of Songs, and his sample of contemporary songs: eros, patriarchal marriage, masterservant, and parent-child. Of these, Goodman claims only one is "hinted at" (222) in the Song of Songs. This is a fair observation as the presence of the divine in the Song of Songs cannot be accounted for in the text and yet neither can it be discounted. However, Goodman goes on to make such claims regarding the Song that it "does not depict hierarchy between the lovers" and "does not explore this metaphor [parent-child] in the relationship between the lovers." I am surprised at Goodman's conclusions here given the Song is one where lovers may overwhelm each other (Song 6:5) and where one lover may say of the other they are awe-inspiring/terrifying (Song 6:4, Io). The lovers of the Song clearly find power part of the erotic play. Ironically, earlier in the book, Goodman makes this very point about the Song, calling it "a fantasy about marriage, with one or both of the lovers playing at royalty in ways which both uphold and undermine traditional power relations" (I 83). The parent-child metaphor is another with which the Song's lovers intersect, for example, where one lover dreams of the other at her mother's breast (Song $8: \mathrm{I}$ ); where one lover will seduce the other in the same place that his mother gave birth to him (8:5); or, in another erotically charged scene, where one 
lover feeds the other with pomegranate juice in her own mother's room, and at her mother's instruction (Song 8:2).

In Goodman's book there is a tension detectable underneath his apparel of objectivity, perhaps an underlying concern to protect God from indecent sexual exposure. It is perhaps by reason of this concern that Goodman appears to privilege the Psalms, which are undoubtedly less erotically charged than the Song of Songs (20I). This is evident particularly in what he contends is the true mood of biblical voice: that biblical voices actively resist a notion that human sexuality can facilitate encounter with God (234). But the incendiary voice of the Song of Songs, at least, cannot be completely predetermined in this way. Goodman himself regards the boundaries as blurred (4), repeating this assertion of blurring multiple times. It is curious then that Goodman seeks to over-determine boundaries in his conclusions when considering to what degree biblical voices resist the sexualization of God. "The presence of both the Psalms and the Song in the Hebrew Bible encourages canonical readers to see desire for God and sexual desire as neither identical nor opposed, but clearly distinct from each other" (230). The Song, for one, leaves the possibility of this merger or this distinction discomfortingly unresolved.

Goodman provides a strong investigation of his topic, and one which supports the innovative and deeply nuanced engagements of the intersections between sexuality and spirituality provided by Carr's The Erotic Word (2003) and Rob Bell's Sex God (2007). One of the most interesting discoveries from Goodman's work is Bono's short yet insightful introduction to the Psalms from the perspective of a lifetime in the upper echelons of rock " $\mathrm{Hu}$ morous, sometimes blasphemous, the blues was backslidin' music; but by its very opposition, flattered the subject of its perfect cousin Gospel" (The Book of Psalms, [Edinburgh: Canongate, 1999], loc. 77, Kindle edition). This is an astute understanding from Bono of what is at stake in contemporary music when religious language is used-and a point that Goodman does not make as plainly in his own work. The Nine Inch Nails lyric Goodman quotes is one which bears this up. When Reznor writes "I want to fuck you like an animal ... you get me closer to God," he is perhaps not expressing as Goodman suggests "an understanding of sex as a means to intimacy with the divine" ( 197 ) but, as Bono suggests, a kind of resistance, a satire, a deliberate use of religious language to deride, ridicule, oppose and attack the authority associated with religious tradition, and which yet at the same time brings close the very subject it seeks to challenge and deconstruct. Industrial Rock is thus a 
purposeful blasphemy that does two things at once; it resists the status quo, establishment, society with church at its decaying core, and then in spite of itself opens up the possibility of engaging the divine anew, having removed the legalism that separates body and spirit long holding prominence in Christian worldviews. The provocative visual symbolism in the music video in which Reznor performs his song "Closer" provides further indication that this is the case. Goodman largely fails to identify resistance or deconstruction as a motive for the use of religious language in popular music.

As can be inferred from this review, Goodman's Yearning for You was stimulating work that this reviewer found both rewarding and frustrating. This work is well placed in Sheffield's Bible in the Modern World series and is worthwhile engaging. As Goodman may well agree, there is a lot more at stake than sex plain and simple in any relationship, but it is the way language facilitates the play between spirituality and sexuality in song that is fascinating and Goodman provides some grounds for a comprehensive investigation of such. The biblical texts, the many commentators and also singer-songwriters for which Goodman accounts on this topic bear out a multitude of overlaps, intersections and collisions between human-human and human-divine relation, opening up rather than closing down the possibilities that come with encounter.

Yael Klangwisan
Laidlaw College

Sex, Wives, and Warriors: Reading Biblical Narrative with its Ancient Audience, by Philip F. Esler

Eugene: Cascade Books, 20I I | xii + 408 pages | ISBN: 978-I60899-829-6 (softback) $\$ 46.00$

This book has been a long time in the making. The chapter on the madness of Saul, for example, was pre-

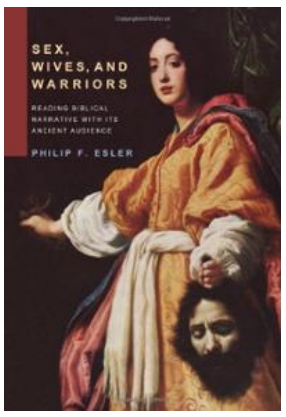
sented during a conference on Biblical Studies/Cultural Studies at the University of Sheffield in 1997 and published soon afterwards; three other chapters (those on Hannah, Judith, and David and the Ammonite war) were published during the early to mid-Noughties. Other significant elements of the 
book will also be instantly recognisable to those familiar with Esler's extensive publications, echoing his long-standing commitments to the social-scientific interpretation of the biblical texts (e.g., Conflict and Identity in Romans: The Social Setting of Paul's Letter [Minneapolis: Augsburg Fortress, 2003]) and to the need for the interested modern interpreter to read these texts in ways directly affected by such interpretation (e.g., New Testament Theology: Communion and Community [Minneapolis: Augsburg Fortress, 2005]). Here Esler attempts to offer a specific model of reading Old Testament narratives for a variety of contemporary audiences and defines it, both explicitly and implicitly, over and against other "competitor" forms of interpretation.

Two opening chapters set the scene for what follows. First, Esler discusses how a variety of reading communities should read the Old Testament. He provides a fourfold categorisation of Bible readers (see below), created by distinguishing between two groups (A, C) of religiously motivated readerslay people and professionals - and two further groups $(\mathrm{B}, \mathrm{D})$ reading for non-religious reasons - again divided into professionals and others.

These groups are graded for population size, with A-"practicing Christian and Jewish lay people" (5) - being the largest and D_ " "professional people reading for non-religious reasons" (6) -being the smallest. It is telling that Esler's B group of lay non-religious types includes only those curious about the scriptures and those who are no longer committed to them, whereas it is group D-the mixed bag of professionals - which includes the creatives, the artists, the film-makers, the composers, and the journalists; as we will see later, this decision about taxonomy has significant consequences. When Esler turns to discuss how these four groups of readers should interpret the texts, he argues that theistic readers (A, C) should be seeking to encounter meanings that are close to those that were experienced by the original audience in their socio-historical context; they will then, he claims, experience these traditional yet fresh readings of the narrative as "readjustments of the collective memory" (Iо) rather than as mere textual reinterpretations (an experience which Esler relates to his own personal childhood experience of bible study; IO-II). He goes on, however, to suggest that such readings can also be usefully encountered by the non-religious groups (B, D) as an educative intercultural message delivered from the past, which discloses "more ample possibilities for being human" (I I). These messages are not to be related to the historical events behind the texts, however, but to the narratives as interpreted within their earliest history, and the chapter concludes with a technical discussion of "story elements and story structures" (27-34). 
A MODEL OF READERS OF THE OLD TESTAMENT

Readers for Religious Reasons

A.

Practising Christian
and Jewish lay
people

Non-Professional Readers
B.

One-time Jews and
Christians
Curious people and
searchers
searchers
C.

Believing Jewish and Christian biblical critics
Believing
undergrads and
postgrads in
biblical studies
Priests, ministers, rabbis
Believing artists, composers, etc.

D.

Professional Readers

Agnostic/Atheist biblical critics

Comparative lit critics and students

Literary critics and art historians

Artists, filmakers, composers, journalists, etc.

\section{Readers for Non-religious Reasons}

Table after Esler, p.4.

Second, and having thus justified its necessity (to his own satisfaction, at least) in chapter I, Esler provides an anthropological account of the original context of the Old Testament texts, briefly setting that methodological approach in historical context before focusing on the "usual suspects": the "material conditions" of villages and families; the group-oriented nature of the ancient Israelites; their notions of honour and shame; the competitive, agonistic nature of their society; the concept of limited good; the presence of patrilineality, patrilocality, and polygyny; and the broad political and socioeconomic structures of Israel, focusing on the elite/non-elite divide. (Later chapters will expand on these as and when Esler deems it appropriate.) A 
discussion of the extent to which Israel was a high-context culture, able to express a complicated message within a few words, completes the chapter.

Taking as his key themes wives, warriors, and sex (with the latter being demoted inside the volume's covers for some unexplained reason from its alphabetical primacy in the title), Esler then offers three "Parts" under those headings, containing eight studies of individual texts in total, each of which reads the relevant text against its ancient socio-cultural background. For Wives, we have the stories of Judah and Tamar (Gen 38) and of Hannah, Peninnah, and Elkanah (I Sam I-2); for Warriors, Saul (I Sam 8-3I), David and Goliath (I Sam I7:I-I8:5), David, Banditry, and Kingship (I Sam I 9: I-2 Sam 5:5), and Judith the Female Warrior (thanks presumably to Esler's use of the Catholic canon); and for Sex, we have David, Bathsheba, and the Ammonite War (2 Sam Io-I2), and Amnon, Tamar and Absalom (2 Sam I3). A brief epilogue completes the volume.

I will leave it to other readers of the book to critique Esler's individual readings within the eight textual chapters (four of them, of course, have already been available for some time). All that I wish to say about them in a review in Relegere is that they illustrate very clearly the point that I was trying to make in my essay on the state of the discipline of New Testament Studies (and thus Biblical Studies more widely) about the virtually mandatory discussion that any contemporary historical-critical interpreters must offer about a text's ancient audience, their context, and their expectations (cf. "Hope for a Troubled Discipline? Contributions to New Testament Studies from Reception History," JSNT 33 [2010]: 207-220). I'd also throw into the mix here Peter Oakes's Romans in Pompeii: Paul's Letter at Ground Level (London: SPCK; Minneapolis: Fortress Press, 2009), which seeks to view Paul's letter though several distinct pairs of eyes, each of which is generated from the kinds of historical data employed by Esler. The present volume is a prime case of a work in the historical-critical mode which can be justifiably categorised as an exemplary work of a certain kind of reception history; Esler is trying to capture the dynamic between the text and its (first) audience and their context, before exhibiting it for others. To my mind, Esler's discussion of the historical context may on occasions feel a little too thin for his readings to be secure-or indeed "fresh" - in the long term, and it is also the case that there have been plenty of critiques of the usefulness of notions like "limited good" in the recent past. But it is also often true that the best readings of any given text have had a bad habit of preceding their full theoretical justification. His other readers can decide such questions for themselves. 
More of a reason for me to offer a review of Esler's book in Relegere is that his work also exemplifies the persistent desire of some in the guild-a powerful many or a decreasing minority, depending upon your viewpointto highlight and seek to validate an extremely narrow band of meanings for a biblical text. Despite the longevity of the growth of some of the Old Testament texts, the assumption that a primary reading community can somehow be identified and raised up as the pristine interpreters whom modern readers should emulate is highly prevalent, especially among those historical critics affected by certain theological dispositions. Esler argues (or perhaps better, asserts strongly) that each of his four groups of readers would best encounter the Bible through his reading approach. For the religious, this involves taking part in a tradition of reading in which their scriptural texts are re-incorporated into the community's corporate memory in fresh and invigorating ways. For the non-religious, this is the method by which they will encounter "more ample ways" of being human. My problem with this type of argument is that it raises two distinct and problematic issues because of its general unwillingness to allow other biblical interpreters to exist alongside it unmolested.

The first issue relates to the taxonomic decision through which Esler's artists were collected together as a distinct group of professionals. Such figures are clearly no longer being allowed to encounter the text as eclectic and creative amateurs in their own right. In Esler's view, these individuals are in fact better characterised as people who simply do not realise what the Bible that they hold in their hand can offer them; he seeks "to explain [to them] how Old Testament narrative, understood in the manner set out in this book, has a richer capacity to stimulate their creative instincts than they may have anticipated" (6). It is this view on the narrow meaning and its efficacy which also drives his claim that his approach offers "more ample possibilities" to be human. Ironically, a narrow band of meaning is being said to provide greater variety and richness than a consideration of the interpretive history of the text as a whole can do. It should be clear that I have no problem with Esler claiming that such a narrow focus certainly offers "additional" possibilities; only by denigrating the creative capacities of a Michelangelo, a Laurence Stern, or a William Blake, however, could I even begin to agree that the possibilities for consideration of what it is to be human offered by/through the original meaning (or something like it) were more ample or richer than those offered by the multitudinous historical traditions that have treasured and used these texts. I just can't do it. 
This leads directly to the second issue. Esler's readings are perhaps all well and good, informative and challenging to modern readers of almost any ilk, but they were simply not available to most of the multitudes of earlier readers - whether religious or non-religious, lay or professional-who have used these texts over the last two thousand years; did they really not know what it meant to think profoundly about the nature of humanity? We in the modern Westernised world are seemingly doomed forever to an existence haunted by the readings suggested by a historical consciousness which is in fact totally alien to those interpreters whom we often condescendingly term pre-modern. I am convinced that it is fallacious - and for Esler and his Catholic religious tradition, bizarrely self-defeating-for us to argue/assume that our historically contextual fixation on specific forms of meaning which (almost) ape the readings of the ancients somehow means that we have found the one and only entryway into insightful biblical meaning. Here a second point raised in the JSNT essay rears its head. Meanings can be defined as good or creative or important by things other than the canons of the modern anthropological study of the ancient world. Yes, that approach may give us insight, but it is certainly not the only, or even best, route to it; any one churchperson who insists that it is has basically accused their deity of gross negligence, it seems to me! It would befit a volume such as Esler's if it exhibited a deep sense of humility, did its own thing, and let the audiences that it has tried to corral decide upon the validity of its story accounts. The idea that an audience of interested onlookers such as artists, film makers, and so on, cannot decide on what is or is not to be a creative use of a biblical story would be puzzling, were it not so laughable. Creative biblical interpretation — whatever it may be! — does not belong to a guild at all; arguably it never has. Those historical critics who accept the arguments of my JSNT article that their work is a form of reception history (e.g., Larry W. Hurtado, "On Diversity, Competence, and Coherence in New Testament Studies: A Modest Response to Crossley's 'Immodest Proposal," Relegere: Studies in Religion and Reception 2 no. 2 [20I 2], 353-64 [36I-62]) would do well to remember that I also argued that what is really important is often not what we moderns think it is. Expecting others to agree with our assessments of what is important usually leaves us only looking rather foolish, especially if we persist in asserting or arguing for it forcefully. I cannot deny that I would like more books like this one to be published, but I do not need future versions to commend their methods as valid for all and sundry. Offer me a reading and I will happily judge its place and rightness. If I can 
do that, then so can many, many others, especially those creative users of the Bible whose interpretations often make ours look dull by comparison. The historical-critical guild does not own these texts or necessarily read them best; it should grow up, realise it, and wind its neck in a bit.

\section{William John Lyons \\ University of Bristol}

\section{The Practice of the Bible in the Middle Ages: Pro- duction, Reception and Performance in Western Christianity, edited by Susan Boynton and Di- ane J. Reilly}

New York: Columbia University Press, 2012 | 376 pages | ISBN: 978-0-23 I-I 4826-9 (hardback) \$89.50 | ISBN: 978-0-23 II 4827-6 (softback) $\$ 29.50$

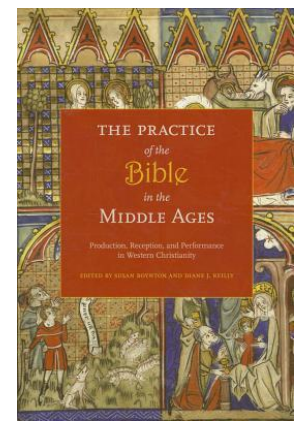

This collection of articles provides an overview of the reception, transformations, and uses of biblical texts in the Christian Middle Ages, focusing on its manuscript tradition. The volume consists of fourteen chapters and an introduction ("Orientation for the Reader"). The chapters are organised by chronology and theme. The first chapters (2-4) deal with the Bible in a monastic context, especially that of the Early Middle Ages. The next four chapters (5-8) focus on transformations in the reception of the Bible through the eleventh and twelfth centuries. The second half of the book (chapters 9I 5) focuses on the thirteenth century, while also considering the period up to the end of the Middle Ages. Two of the chapters (9-10) in this section are dedicated to the Mendicant Orders, two to a specific example of biblical codex (eleven to the Paris Bible and twelve to the Illustrated Psalter) and the final three $(13-15)$ to translations of the Bible into English, French and Castilian respectively. The methods and expertise of scholars from a wide range of disciplines (theology, musicology, history, codicology, or literature) provide an interesting variety of perspectives. The editors have been able to compile a set of articles that conveys a sense of completeness and that addresses the most relevant aspects of the chosen subject. Each chapter can be read autonomously, but they frequently refer to one another and are wellorganised in the volume. 
The book is a valuable introduction for people who are not specialists in the area but who have a basic knowledge of biblical studies or medieval culture. The "Orientation for the Reader" and the glossary easily allow the amateur to become acquainted with some fundamental aspects of the subject. Both might seem rather elementary to many, but they guarantee that the reader is able to find most of the necessary background information on the book itself. The "Orientation" also contains some useful final paragraphs reviewing relevant literature on the subject of the volume. The language of most of the articles is also easily readable. The goal stated in the acknowledgements of being "understandable to the broadest possible audience" (vii) is widely met.

The title of the volume subdivides the "Practice" of the Bible in the Middle Ages into three distinct activities, namely "production, reception and performance." These are, however, not represented equally in the volume. Production and reception stand out, while performance is seldom chosen as a subject. Nine of the fourteen chapters focus on biblical manuscripts and the way their material traits reveal the interpretation and use of a text. The articles show distinctly and with relevant examples how multiform biblical texts and codices in the Middle Ages were and how the modern Bible is the result of a process that lasted many centuries. Other means of dealing with the reception and uses of the Bible include the analysis of its translations and illuminations, as well as its influence on medieval conceptions of history and theology. The chapters dealing with the historical, theological or philosophical reception and uses of the Bible $(2,4,5,8$, and 9$)$ are very general, perhaps due to limited space, but they all cope with the problem of explaining difficult issues in a few words. In spite of the merits of the volume, a more detailed treatment of "performance" is widely missed. Only two chapters (6 and Io) address the problem directly, while another few do it marginally (for example, chapter I 2). It is certainly one of the most difficult and uncertain aspects to analyse, but remains a subject which deserves more attention after being traditionally left out of scholarly investigation.

I would now like to make a brief commentary on each of the articles. Susan Boynton, co-editor of the volume, writes on "The Bible and the Liturgy." The focus lies, as expected, on the Psalms, the most important of the biblical books used in the liturgy. The author states that "the selection and combination of biblical texts in the chants and readings of the liturgy constitute a system of interpretation" (Io). The thesis is argued with convincing examples. However, this reader would have liked to find a more developed 
reflection on the performance of the Bible in liturgical contexts. Only in the final part of the chapter, when dealing with dramatic representations of biblical subjects, does performance receive more detailed attention.

Chapter 3, "Early Medieval Bibles, Biblical Books, and the Monastic Liturgy in the Beneventan Region," by Richard Gyug, continues dealing with the relationship between the liturgy and the Bible, but limits its corpus to the biblical codices produced in the Beneventan script. The purpose of the article is to show the importance of liturgy for the organisation of many biblical manuscripts. Biblical codices depended strongly on their liturgical use and were adapted extensively to it. The article is a great example of exhaustive textual criticism applying statistical methods to a relatively large number of textual accounts.

Chapter 4, "When Monks Were the Book: The Bible and Monasticism (6th-I I th Centuries)," by Isabelle Cochelin, is an interesting account of the role played by the Bible in the life of monks up to the eleventh century. The Bible was taken as a model for the foundation of a community, for the yearly calendar and for daily activities. The article shows that the Bible was present in almost every aspect of monastic life, organising it and giving it meaning.

Chapter 5, "The Bible and the Meaning of History in the Middle Ages," by Jennifer A. Harris, is an account of Christian historiography up to the twelfth century. In very few pages Harris summarises with great clarity the main issues addressed by Christian historiographers and highlights the role of the biblical narrative in this. The author states that the salvation story in the Bible was used as the model for all historical writing and could be adapted in various ways to solve the main problem of medieval historiography: the explanation of historical change.

Chapter 6, "Lectern Bibles and Liturgical Reform in the Central Middle Ages," by Diane J. Reilly, co-editor of the volume, is a good example of how codicology can be a powerful tool for understanding the uses, functions and interpretations of biblical texts. She analyses large lectern Bibles from the eighth up to the twelfth centuries and explains how form, script, and especially size indicate the function of a biblical manuscript. Reilly argues that lectern Bibles did not perform a purely symbolic function as luxury articles, but were also used to support the renewed liturgical life in the monasteries. The thesis is very convincingly argued. The second part of the article focuses on the functions of the decoration of these manuscripts in the context of the liturgy, as an aid to memorization and as an interpretation of the biblical text. 
Chapter 7, "The Italian Giant Bibles," by Lila Yawn, deals with a particular type of biblical codex, the Bibbia Atlanticae, giant and luxurious Bibles composed in the twelfth century. The expensive and difficult production of the codices and the people involved in it (patrons and scribes) are extensively analysed. The author takes a stance in the scholarly discussion about the origin of the Bibbia Atlanticae. She argues that they were not originally produced in Rome, but to the north, in the region of Tuscany and Umbria, and that they were manufactured by professional artisans hired for that purpose. The final part of the article focuses on the illustrations, especially on how they render the purposes of the patron.

Chapter 8, "Biblical Exegesis Through the Twelfth Century," by Frans van Liere, summarises the Christian theories of interpretation from the Early Middle Ages through to the twelfth century. It manages to explain such a complex subject in very few pages. Sometimes the article does name too many theologians without being able to expand on their contributions to the history of exegesis, but it is an accomplished introduction to the subject.

Chapter 9, "Mendicant School Exegesis," by Bert Roest, summarises the works of the most notable theologians of the thirteenth century who were also members of mendicant orders. Thomas Aquinas and Bonaventura receive detailed attention. The author also analyses attempts at textual criticism in several medieval theologians, Joachimism, and the Commentaries of Nicholas of Lyra. The last part of the article focuses on the decline of mendicant exegesis in the universities, as the study of biblical texts was being replaced by other textbooks and speculative theology. However, the author argues that the practice of mendicant exegesis continued living in preaching and in some marginal centres of learning, a topic which should receive greater scholarly attention in the future.

Chapter io, "A Ladder Set Up on Earth': The Bible in Medieval Sermons" by Eyal Poleg, deals with the role of the Bible in medieval sermons and the historical changes in this practice. The author explains the formal traits and historical transformations of medieval sermons and explores the preacher's awareness of the audience, the gap between extant sources and medieval reality, and the ways in which preachers expanded and interpreted the biblical text in order to fulfil various aims, such as moral injunction and commentary on the liturgy. Of all the articles in the book, this is the one which pays closest attention to how the biblical text was part of a performative act. The thesis that sermons pre-dated humanists and reformers in celebrating contradictory biblical readings and bringing increased attention 
to the Semitic roots of the Vulgate seems arguable. However, this chapter stands out in the context of the volume for focusing on the performative aspect of the biblical text.

Chapter II, "The Bible and the Individual: The Thirteenth-Century Paris Bible," by Laura Light, has a quite misleading title, as the problem of individuality is not addressed at all. It is a very clear and didactic chapter on one of the most historically important types of biblical manuscript, the so called Paris Bible of the thirteenth century. The chapter deals with the importance of the market and the University in establishing and configuring the text. The uses, formats, and transformations of the Paris Bible as well as some fundamental methods of biblical textual criticism are explained very clearly.

Chapter I 2, "The Illustrated Psalter: Luxury and Practical Use," by Stella Panayotova, explores the continuous presence and profound influence of the Psalms in the life of men and women in the Middle Ages. It is probably the only chapter in the volume to analyse all the practices listed in the title: "production, reception and performance." It is a very complete account of how psalters were shaped by the people producing, reading, and using them in a great variety of ways (from a political and ideological tool to a magical instrument) as well as how their texts helped medieval people in shaping and understanding life. In my opinion, it is one of the most interesting and accomplished chapters in the volume.

Chapter I3, "The Bible in English in the Middle Ages," by Richard Masden, analyses various translations of biblical texts into the English language, from the early Anglo-Saxon glosses on the Latin text to the complete translations of the early Reformation. Many kinds of text are considered: vernacular texts on biblical subjects, translations of specific passages in the context of a vernacular text, translations of some biblical books, and translations of the entire Bible (especially that by Wycliffe). The most important issues addressed are the method of translation (word by word or adapting the text to reproduce the meaning) and the political significance of each translation.

Unlike the other two chapters on vernacular Bibles, chapter I 4, "The Old French Bible: The First Complete Vernacular Bible in Western Europe," by Clive R. Sneddon, has a confusing structure which sometimes makes it difficult to follow. This is perhaps due to the author's decision to reconstruct the history of scholarly criticism on the Old French Bible. On the positive side, this structure shows the problems that scholars encounter when investigating these codices. One merit of the chapter is that it provides personal theses 
about the context of the production and use of the Old French Bible. The author claims that it is a product of the period I220-I260, probably made in Paris, for the edification and devotional use of wealthy lay-people.

Chapter I 5, "Castilian Vernacular Bibles in Iberia, c. I250-1 500," by Emily C. Francomano, is a very detailed article which explains the role of Castilian translations of biblical texts in the context of the written and intellectual tradition of the Iberian Peninsula. It is the article which pays the closest attention to the links between Christian, Jewish, and, in minor detail, Arab exegetical traditions. The author tries to determine the intended audiences and readerships of these Castilian Bibles through a careful and convincing analysis of the remaining traces of the translation process.

The volume as a whole deals with all the main issues in the reception history of the Bible in medieval Christian Western Europe. It is no groundbreaking book, nor does it intend to be one. It is however a very clear and enjoyable introduction to the transformations and uses of the Bible throughout the Middle Ages. The volume reminds us that the Bible was not a unified book, that its use was multi-faceted, and that it helped to shape the thinking and ways of life of men and women in Western Europe throughout many centuries.

Gustavo Riva

University of Buenos Aires

\section{Shakespeare, the Bible, and the Form of the Book: Contested Scriptures, edited by Travis DeCook and Alan Galey}

Routledge Studies in Shakespeare 5 | New York and Abingdon: Routledge, 20I 2 | xi + 207 pages | ISBN: 978-0-4I 5-88350-4 (hardback) £95.00

Why do Shakespeare and the English Bible seem to have an inherent relationship with each other? How have these two monumental traditions in the history of the book functioned as mutually reinforcing sources of cultural authority? How do material books and related reading practices serve as specific sites of intersection between these two textual traditions? This collection, stemming from simultaneous 
post-doctoral fellowships held by the editors in 2006-7 at the University of Alberta, makes a significant contribution to our understanding of Shakespeare, the Bible, and the role of textual materiality in the construction of cultural authority. Departing from conventional source study, it questions the often-naturalized links between the Shakespearean and biblical corpora, examining instead the historically contingent ways these links have been forged. The volume brings together leading scholars in Shakespeare, book history, and the Bible as literature, whose essays converge on the question of scripture as source versus scripture as process-whether that scripture is biblical or Shakespearean. They explore themes such as cultural authority, pedagogy, secularism, textual scholarship, and the materiality of texts. Covering an historical span from Shakespeare's post-Reformation era to present-day Northern Ireland, the volume uncovers how Shakespeare and the Bible's intertwined histories illuminate the enduring tensions between materiality and transcendence in the history of the book.

The merit of this collection is to develop the implications of the fact that Shakespeare and the Bible are not binary, stable, and unproblematic texts. The essays in the collection consider the period's conflicting Bible versions in the context of theological, political and social meanings and the effects of "Scripture's contested status as a material and historical artifact on Shakespeare's literary production" (9). The instability of the text is clear: we have no autographs for Shakespeare's plays or any of the books of the Bible. In Shakespeare's lifetime, a number of translations of the Bible were in circulation. Not only is the canonization of the Bible itself a disputed process, but the Bible was also frequently translated and interpreted and it was vulnerable to the corruptions of transmission. Thus, if word-choices Shakespeare makes in his plays do not match the printed text of the Great Bible (I 538 ), the Geneva Bible ( 1560 ), the Bishop's Bible (I 568), or the King James Bible ( 6 I I ), gimlet-eyed readers would do well to consult marginal glosses in all texts as well as contemporary commentaries, liturgical texts, devotional materials, and sermons on the texts themselves. Indeed, some of Shakespeare's allusions derive from the Book of Common Prayer (I 549). Such readings attest to the wide and deep impact of these Bible translations so soon after their genesis. These intersections encourage us to ask how Shakespeare's writings "negotiate the increasingly diverse material forms through which Scripture was mediated and accessed in his era" (I I).

By the end of the study we can see something of the contours of the interaction between these two collections, both material and metaphorical. The 
particular material forms of these two works shape the texts' cultural authority as well as intersecting histories of transmission. (A review such as this cannot do justice to all the essays.) In her essay, "Shakespeare reads the Geneva Bible," Barbara Mowat writes on the effect of the Geneva Bible's paratextual meditations for Shakespeare's adaptations of biblical material, particularly the Cain and Abel story of Gen 4:I-I 6. She argues that not only does Shakespeare draw on marginal glosses that go beyond and even fix the text, but his dramaturgy also depends on the intertextual cross-referencing system of the Geneva Bible. A marginal gloss to Gen 4, "the dignity of the firstborn is given over to Cain over Abel" surprisingly interprets the fratricide as a matter of inheritance and blessing (rather than murder, for example). And this is the way Shakespeare uses the story of the two brothers. In another case, Mowat argues that marginal glosses at Exod 2 I:23-25 (the lex talionis) to the Sermon on the Mount in Matt 5 may be reflected in Measure for Measure in the Duke's phrase in a dialogue with Isabella, wherein "the very mercy of the law" is a reminder that she respond not just with justice but also with forgiveness.

Scott Schofield's essay, "Cain's Crime of Secrecy and the Unknowable Book of Life: The Complexities of Biblical Referencing in Richard II," demonstrates how Shakespeare's biblical references need to be considered in light of contemporary commentaries, exegetical texts, liturgical materials, sermons, polemics, and other paratextual materials surrounding Bibles.

In the nineteenth century, Andrew Murphy argues in his essay, "'Stick to Shakespeare and the Bible. They're the roots of civilisation': NineteenthCentury Readers in Context," working class people across professions and geography "registered a deep identification between the two texts," perhaps the result of the newly generated educational curriculum and the book market. Early educational institutions were run by churches and after memorization and extensive reading of the Bible, Shakespeare's cultural status made his plays a natural choice and the language accessible. Such an affinity he characterizes as parasitic and symbiotic. It continues to the present: think of the $\mathrm{BBC}$ radio program, Desert Island Discs in which famous people imagine music choices that might accompany them to a desert island. They are always given the Bible and Shakespeare.

This collection of essays is rich and stimulating. I commend it highly to those interested in the contested material and cultural intersections of Shakespeare and the Bible. David Daniell's assessment (cited on page 36) is a fitting conclusion: he says that "the Bible for the Tudors ... was the life-blood, 
the daily, even hourly, nourishment of the nation and of ordinary men and women. It was known with a thoroughness that is, simply, astonishing."

Deirdre Good

General Theological Seminary

\section{Breaking Boundaries: Female Biblical In- terpreters Who Challenged the Status Quo, edited by Nancy Calvert-Koyzis and Heather Weir}

New York and London: T\&T Clark, 2010 | viii + 2I4 pages | ISBN: 978-0-56759-503-4 (hardback) £70.00 | ISBN: 978-0-56737-503-2 (paperback) £24.99

Nancy Calvert-Koyzis and Heather Weir are familiar to scholars interested in the recovery of women's interpretations of the Bible as the editors of the 2009 volume Strangely Familar: Protofeminist Interpretation of Patriarchal Biblical Texts (Atlanta: SBL, 2009). Weir also collaborated with Marion Ann Taylor on an earlier volume concerning nineteenth-century women's interpretations of Genesis (Let Her Speak for Herself: Nineteenth-Century Women Writing on Women in Genesis [Waco: Baylor University Press, 2006]). The business of recovering women interpreters of biblical texts is still in its early stages of research, and the field owes a deep debt of gratitude to these intrepid investigators and their collaborators who have contributed to Breaking Boundaries. Although one or two of the contributors in Breaking Boundaries are working from their primary field of training, the majority are stretching themselves to perform scholarly research that goes far beyond the areas in which they were trained. These persons are, in both senses of the term, amateurs. They work out of love for their subject and bring to light much that is valuable. But one cannot read this volume without an acute sense of the lack of professional depth that characterizes most of the articles. Yet if we waited for the professional historians of these various time periods to deal with the issues raised here, we might well wait forever. Thus gratitude tempers critique.

The design of the volume is elusive. The title, Breaking Boundaries, suggests that the figures considered will have been transgressive in various ways, and while this is characteristic of many, some of the figures considered seem 
to have used their writings to reinforce dominant ideologies and to have stayed well within the boundaries of what was considered proper for educated women of their time. That is not to say that these women are not of interest to the recovery of the history of women biblical interpreters, only that the title may protest a bit too much about the nature of their activities. Similarly, the chronological scope is odd. There is one woman from late antiquity, one from the Elizabethan/Jacobean period, and the rest from nineteenth- and early twentieth-century Great Britain and North America. Limiting the book to the latter cultural location would have given it a clearer focus. Also odd is the fact that two articles on Harriet Beecher Stowe by the same author are neither grouped together nor coordinated with one another.

One aspect of editorial design is particularly welcome. The editors appear to have asked writers to be particularly careful to establish the intellectual and socio-cultural context of each of the women considered, and in the best of the articles this contextualization lends a fascinating light on the hermeneutical issues involved in the particular interpreter's work.

Brian Sowers, who is trained in classics and early Christian literature, examines the Homeric cento of Eudocia, the wife of emperor Theodosius II (fifth century). In some respects the account of Eudocia's literary remains reads like a narrative by Jorge Luis Borges, since the manuscript evidence is insanely tricky, and many of the accounts about Eudocia are tinged with legend. The literary form of the cento itself involved the composition of a poem (here the life of Christ) using only lines already extant in Homer or another classical author. Eudocia's own cento was not an original composition but a revision of that of Patricius. Her revision of Patricius was then revised by Optimus, etc. The object of inquiry threatens to vanish into uncertainty. Sowers is able to show, however, with some persuasiveness, that one can still see the hand of Eudocia at work. Particularly through her cento's presentation of Jesus's encounter with the Samaritan woman, she focuses issues of concern in her own time with respect to women's options of celibacy or marriage.

Caryn A. Reeder gives a good introduction to the intellectual context and major work of Aemilia Lanyer (Salve Deus Rex Judaeorum, I6I I), the remarkable feminist poet of early seventeenth century England. Her work is appropriately situated within the querelle des femmes, the centuries-long European literary dispute over the virtues and vices of women. Lanyer's radical hermeneutics in reinterpreting Gen I-3 (through the voice of Pilate's wife, no less) in contradiction to the prevailing misogynistic interpretation is remarkable. Lanyer's work is readily available on the web at several sites and 
deserves to be integrated into the history of the reception of Gen I-3 much more centrally.

Heather E. Weir discusses Sarah Trimmer's An Easy Introduction to the Knowledge of Nature and Reading the Holy Scriptures (1780). Trimmer was an author of books in religious education for children. Weir persuasively situates her less in the context of early science or environmental education, as others have considered her, and more in the context of natural theology. Nevertheless, it is difficult to see exactly how Trimmer qualifies as one who broke boundaries, as she seems to communicate in a genre acceptable for women writers, more or less what other educated and progressive men were doing at the time.

It is even more difficult to bestow the epithet of boundary breaker on Eliza Smith's The Battles of the Bible (1852), which is the topic of Bernon Lee's essay. Smith cast her book as a conversation between a grandfather and his grandchildren concerning the battles narrated in the Bible. What Lee helpfully brings out is how Smith's interpretation often picks up on isolated details in order to advance a social agenda of middle class virtues (industry, honesty, self control, etc.) in the context of the Scottish middle class's attempt to "pry the church apart from upper-class interests" (8I) in order to address the plight of the working class. While a fascinating account of socio-cultural struggles played out in biblical education, it is difficult to see how Smith's gender is interpretively significant to the nature of what she did. Her class and social location seem much more germane.

One sympathizes with the task of J. Glen Taylor, who attempts to contextualize Joana J. Greswell's Grammatical Analysis of the Hebrew Psalter (I 873). Though some things are known about Greswell's family, very little is known about her personally. Moreover, her work, as a technical work of scholarship, lends itself only with difficulty to ideological placement. Taylor does draw attention to the fact that Greswell's book was prefaced by endorsements by male scholars. Since this was a feature of other women's books in the nineteenth century, it would have been useful to explore this phenomenon comparatively, so as to frame more clearly the means by which women negotiated the resistance to their entry into largely male fields of scholarship.

Nancy Calvert-Koyzis contributes two essays on Harriet Beecher Stowe's interpretations of the Virgin Mary and Mary Magdalene in mid-nineteenthcentury America. The Virgin Mary is interpreted in relation to the Victorian cult of true womanhood and the theory of separate spheres of women and men. But Stowe's interpretations are also related in this article to her 
own personal history of the death of two of her children. The ambivalence of Beecher Stowe's own public role and her championing of a more private role for women is palpable. Nevertheless, her radical call to reform the nation in the image of feminine virtues is well articulated. The essay on Mary Magdalene underscores the conflict among women interpreters of the era concerning whether to accept or contest the traditional association of Mary Magdalene with the "sinful woman" of Luke 7. These essays would have been more effective if they had been conceptualized more as a coordinated pair of articles and juxtaposed in the volume.

Beth Bidlack's essay on Olympia Brown (I $825-1926$ ) provides a good biographical and contextual account of this pioneer in women's ordination and women's suffrage, but one wishes that it was more thesis-driven. Similarly, Rebecca G.S. Idestrom's essay on Elizabeth Mary MacDonald (I897-I984), provides an engaging report on the dissertation of the first woman to get a Ph.D. in the department of Near and Middle Eastern Studies from the University of Toronto, who wrote on "The Position of Women as Reflected in Semitic Codes of Law" (1928), but the essay never quite finds a focus.

Perhaps the best essay in the book is that of Kristin Kobes Du Mez on the work of Katharine Bushnell (I 855 -1946) and Lee Anna Starr (I $853-1937$ ), two women who engaged in what we would recognize as feminist hermeneutics but who rejected both the iconoclastic freedom embraced by Elizabeth Cady Stanton's approach to the Bible and the historicizing hermeneutics of the emerging higher criticism. As Du Mez argues, their quite sophisticated and bold hermeneutics was largely disregarded because "Bushnell and Starr did not fit securely within either the conservative or the liberal factions of an increasingly polarized faith" (I66). One hopes that Du Mez's article will help restore these women to a more significant place within the history of feminist scholarship.

Though Breaking Boundaries has its shortcomings, the intellectual work of the recovery of women interpreters remains in its infancy, and one can be grateful for what has been retrieved and presented here. The volume does, however, point toward the need of biblical scholars to collaborate more fully with our counterparts in the intellectual and cultural history of the periods in which we are interested. The result of such collaborations will certainly enrich both biblical studies and historical studies. 


\section{Recruiting Young Love: How Christians Talk about Homosexuality, by Mark D. Jordan}

Chicago: University of Chicago Press, 20II | xx +273 pages | ISBN: 978-0-226-41044-9 (hardback) \$35.00

This very fine book follows the author's highly regarded work, The Invention of Sodom in Christian Theology (Chicago: University of Chicago Press, 1997), which explored the creation of the category of "sodomy," placing homosexual acts at the very extreme end of sinfulness. This is a similarly careful book, which works from a wide variety of published and unpublished sources to explore the changing language which the churches have used about homosexual acts. It is another case of a very fine publication by University of Chicago Press in this field.

The range is broader than the title might suggest. Ten very solid chapters begin with a fine chapter on the first exploration of adolescence by $\mathrm{G}$. Stanley Hall in 1904 and then extend back to the development of a language of homosexuality linked to Krafft-Ebeling and Havelock Ellis. The second chapter on "First Reports of Hidden Worlds" takes up a second contextual factor: the work of Kinsey from his first report in 1948 and responses by various people including Reinhold Niebuhr and Gore Vidal. Chapter 3 looks at the early considerations by mainline Protestant churches, and the notable writing by Sherwin Bailey. I found it fascinating to see the context of Bailey's pioneering work. While the purpose of this book is not to construct a narrative, one is implicit within the search for the developing language of Christians about sexuality, and this was particularly interesting in making sense of the early writing on Christianity and homosexuality.

Chapter 4 traces the emergence of "homophiles," church people seeking to reconcile homosexuality with Christianity. None of these authors is major, but each is contextualised with care. Chapter 5 begins with the British Quaker report, the first to propose that there should be no barriers to full participation by homosexual people in the life of the churches and discussions in America. In chapter 6, the mythology of the Stonewall riots is superbly critiqued, and this chapter has at its core a study of Troy Perry, the founder of the Metropolitan Community Churches. As Jordan argues, Troy Perry is every bit as significant as the secular Stonewall riot and earlier as well. The 
chapter also looks at John T. McNeill the notable Catholic liberation writer. In chapter 7 we turn back to the conservatives and the fear of children, with a most interesting account of the rhetoric of Anita Bryant. This really is the book at its best. Chapter 8 traces the emergence of Exodus, and various other anti-gay organisations. Then in chapter 9, Jordan looks at the way the AIDS epidemic changed the rhetoric and led to the outrageous statements of Jerry Falwell that this was God's particular judgement on homosexuals. The debate in the I980s grew more bitter and polemical. The final chapter looks at the voices of young people and for young people. The conclusion is on "How Not to Talk about Sex in Church."

This is a fine set of studies and is suggestive of the history of homosexuality and the churches. In none of these cases, however, is the actual history traced; the focus is rather on the changing rhetoric surrounding homosexuality, and so what is traced is a series of broad cultural shifts. This is a very significant approach, for it enables us to understand that in the I960s the medicalised understanding of the "invert" predisposed observers to cast it as a medical or psychological issue, if not as a moral evil. Later shifts of language mean that campaigners like Anita Bryant and Jerry Falwell steadily amended their language to make it a moral choice, and began to make distinctions between orientation and practice, which could not have been conceived when it was viewed as a sickness. All this casts light on the current marriage debate for example, although the author does not particularly address it. In effect if homosexuality just "is" as a way of being and relating, then refusing it recognition is that much more difficult. At the same time, in effect in this history nothing actually happens except the change of language use, as is the current fashion, leaving history without any particular agents, and theology with just an analytical task. Yet this is the very best of the current style of histories of language, because sexuality is in essence a concept, and the changing categorisation of it is particularly important, and although the author analyses changing language use, his deft analysis gives us careful indications of events beyond the changing linguistic patterns. Moreover this is an exceptionally crafted book, written with passion, clarity and a high tone of thoughtful rhetoric. I recommend it with enthusiasm.

One little interesting note. The author draws attention to a book, Christianity and Sex Problems by Hugh Northcote, whom he describes as an Anglican vicar from New Zealand. I was intrigued by this vicar of Lincoln who corresponded with Havelock Ellis and found that he went on to serve as an Anglican chaplain in France before retiring to Christchurch. His 1906 book 
comes on top of two books on women's equality and on Prohibition. His Sex book was published in America and several times reprinted there. Only one copy is held in New Zealand, but many of his examples are drawn from this country. It is an interesting example of the ways in which changing values are reflected in this country.

Peter Lineham

Massey University

\section{The Juvenilization of American Christianity, by Thomas E. Bergler}

Grand Rapids: Eerdmans, 20I 2 |x + 28I pages | ISBN: 978-08028-6684-4 (hardback) $\$ 50.00$

This is a confessional work of historical missiology that also deserves a wider, secular reading. From the perspective of reception history scholarship, it offers

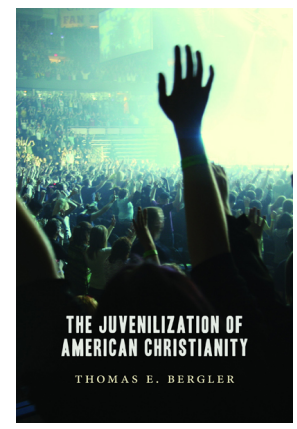
an exemplary study in how religious traditions engage with, accommodate, and resist the emergence of late modern culture in pre- and post-WWII United States. In focussing on four Christian traditions-conservative Evangelicalism, progressive Methodism, African-American Protestantism, and the Roman Catholic church-it is also a more thorough and comparative analysis than one often encounters. Moreover, it demonstrates the reduced importance of religious literacy amongst many ostensibly very religious people, as the emphasis on doctrinal continuity and theological literacy is replaced across two generations with an emphasis on entertainment, activism and therapeutic emotion; the continued transition, in other words, of Christianity from a phenomenon principally grounded in the transmission of scriptural tradition to one grounded in the reproduction of personal experience.

After the introductory chapter, two general historical chapters outline the emergence of this youth-focussed Christianity. Four chapters focus on the four traditions, with chapter 7 analyzing the solidification of the process in the 1960s. A final chapter offers a largely confessional assessment of the phenomenon, but it is one based in solid historical and sociological studies.

The introductory chapter outlines the core elements of the juvenilization thesis: socio-cultural changes that establish a cultural framework for en- 
gagement with religious tradition, albeit generally analyzed via ecclesiological and pastoral phenomena rather than the literary and visual culture reception scholars prefer. Individualization is unsurprisingly significant, but so too is cultural competition as a subset of the broader (but unstated) religious markets thesis; competition exists not only between churches but, most basically, between secular and sacred culture generally. This means creating Christian analogues to secular popular cultural forms, not just music and literature, but sports and even beauty contests. This competition takes place within the broader culture of mass consumerism wherein religion competes to provide both entertainment and the building blocks of identity formation and performance. Enter the professional Youth Minister as part of the further social division and specialization of late modernity that also sees religion generally become an "extracurricular activity" for most American youth. Underlying this is the half-conscious recognition that Bergler brings out very well throughout the book that Christianity is being re-articulated as a "lifestyle enhancement" (220) consisting of "commodities promoting personal fulfillment for those who wish to partake" (I29).

A further constitutive element of juvenilization is the discovery and celebration of youth itself as a distinct social and political subjectivity; a supposedly uniquely energetic people. Chapter I argues that these changes did not originate in the post-WWII period when the emergence of adolescence as a distinct life stage of delayed responsibilities and mass consumerism is generally located, but back in the I930s. This was a time not of hope, but of desperation, when "the potential, peril, and confusion of adolescence seemed to parallel the distress of American civilization" (23). Juvenilization is not intended, therefore, as a (wholly) disparaging term; there was no sense that engaging the world and worldview of young people necessitated a downwards cultural slide. Juvenilization is not infantilization. The view was rather that if the youth do not save (or doom) all humanity, they might at least save (or doom) the church. The problem, as Bergler sees it, is overestimating the political power of youth as an undifferentiated social category-even "a powerful force of nature" (45) — and naïve views of youth culture.

In some ways, Bergler is in synch with conservative Christian critics of popular music and culture. His is certainly not the fundamentalist critique that there is something demonic (or worse, socialist) in post-WWII pop culture, but something like the critique of the renowned scholar of church music Erik Routley who was concerned with the consequences of splitting congregations along generational lines. Routley and Bergler are also both critical 
of the notion that the genre norms of secular youth culture are value-neutral such that these genres can be hollowed out with a spiritual message replacing a secular one. Rather, both argue, genres of popular culture represent and relate to particular subjectivities.

Bergler's juvenilization thesis pivots on the point that the methods used to engage youth mid-twentieth century became the key methods to engaging them - and all subsequent generations of children and adults - in subsequent decades. Indeed, youth ministry is described as a "laboratory" for new expressions of religion that have subsequently stuck. This drift of youth ministry into inter- and cross-generational ministry has led to a "chronic immaturity" (207), the author argues. Yet the crux of the juvenilization problematic is that core elements of juvenilization-particularly focussing on emotion and enjoyment - are shown to "work" in the sense of keeping young people in churches into adulthood. Thus American Evangelicalism emerges, predictably enough, as the most compatible with the emerging culture insofar as believing that humanity would be saved by being converted, and it would be converted by promoting Christianity in an entertaining way as the most enjoyable and personally fulfilling lifestyle option.

Yet it is not merely the Evangelical religious shift into spectacle and what would now be referred to as the experience economy that is responsible for, or constitutive of, juvenilization. Indeed, the interaction between the four traditions is an especially revealing aspect of the study; one gets an excellent sense of how different approaches to emergent changes in American society play themselves out. There is a certain amount of dramatic irony, also, knowing that which is being initially resisted by liberal and politically progressive churches will be shortly incorporated into their practices. Indeed, the Methodists emerge as charmingly naïve in their belief that post-WWII youth would rather selflessly build a more egalitarian America than become "jive hounds" or "hepcats" (48). Amongst progressive Catholic youth, Bergler cites the dilemma of advocating radical reform of the capitalist system among young people who were not only appreciative of the efforts of their parents to achieve financial comfort (and win a place in middle class America once closed to them), but increasingly seduced by consumerism. Rather than criticizing Sinatra for failing to live up to Catholic social teaching, many Catholic youth were happy to have a prominent Catholic to identify with (58-6I).

From a social scientific approach, there are various questions one might raise about the core thesis and the use of data. The book assimilates much of what is very good in the contemporary analysis of religion, youth, and 
culture, including the religious markets theory which, whatever its flaws as a general theory of religion, does make a certain sense, in certain situations, like the United States in the mid-twentieth century. Much of it is unstated, however, and the study could have made better reference to these, in the sense that there are many complementary theories and studies for scholars to follow up, or that simply analyze similar cultural changes from a different perspective. Thus the juvenilization thesis is not especially original insofar as its constitutive socio-cultural changes are well recognized. This is not a criticism, since the same thing could be said of most contemporary theories of social and cultural change. But there is, none the less, a minimum of explicit engagement with proximate cultural and social scientific theory and investigation such that the juvenilization thesis appears more like a theological descriptor when broader social changes associated with liberal individualism become merely "the legacy of teenage rebelliousness" (222).

The juvenilization thesis is most clearly reminiscent of Paul Heelas and Linda Woodhead's better-known subjectivization thesis of religious individualization and detraditionalization in late modernity; notably in its emphasis on personal and emotional connection rather than doctrinal fidelity, coupled with the decline in institutional authority and commitment. This is most apparent in the fifth chapter's analysis of Catholic juvenilization in the I950s; Catholic education produced many confident, critical thinkers-but confident, critical thinkers who were not prepared to accept the religious indoctrination they were offered by these same institutions. Instead, the common notion of spiritual "seeking" took hold. Something similar is analyzed within progressive Methodism in chapter 3; the church promoted social activism which lead to a critical view of the ordered, largely middle class white world of American Methodism itself. At same time, by focussing their energy on youth activism, progressive Methodists, African-American churches, and some Catholic youth organizations lost touch with the vast majority of their members who were not interested in activism-reminding us once again that the I96os counterculture captured only a fragment of the cohort.

Regarding the use of data, one clear issue is the somewhat scattered use of evidence. On one hand this is indicative of the comparative nature of the research; analyzing four traditions over four decades. Yet only occasionally does the study refer to available large-scale studies like Gallop surveys. The focus on changes in the Evangelical Vatican called Nashville in chapter 4's analysis of African-American juvenilization is very revealing, but otherwise data within chapters is rather more eclectic than it might otherwise have 
needed to be. Bergler also over-estimates the current vibrancy of religion in the United States (209-10); recent studies show that Americans born after I 980 are significantly less religiously committed than the generations in this study, the first and second to experience juvenilization. Moreover, the oftrepeated figure of forty percent of Americans attending church each week is based on opinion surveys (which Bergler himself notes often provoke people to provide what they think is the correct answer rather than an accurate answer) which may double the actual number of attendees. This generational decline, combined with the comparative resilience of Evangelicalism (in increasingly Pentecostal articulations), puts an interesting spin on the overall analysis, generally strengthening it.

Ibrahim Abraham

La Trobe University

\section{Anthems of Apocalypse: Popular Music and Apocalyptic Thought, edited by Christopher Par- tridge}

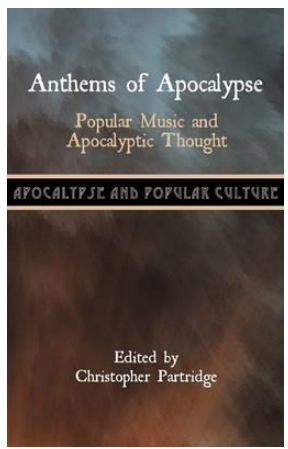

This volume presents a collection of essays that certainly achieves Christopher Partridge's aim to introduce readers to the subject of apocalyptic thought in relation to popular music. While dealing with a vast subject, the eight contributions included provide specific case studies exhibiting the range of apocalyptic resonances in music. Authors thus demonstrate the pervasiveness of apocalyptic thought in popular culture while also gesturing toward further work to be done, establishing frameworks for theorizing generally and analyzing specific examples as models.

In his introduction, Partridge establishes the foundational themes of apocalyptic thought that reappear in the essays to follow. Rather than ranging widely, he focuses on a view of apocalyptic rhetoric related to what he calls "occulture," indicating social currents of subculture in which "spiritual, esoteric, paranormal and conspiratorial ideas emerge, are disseminated, and be- 
come influential in the lives of individuals and in the societies in which they live" (xii-xiii). This sociological approach is useful background for many of the essays-especially since the majority of them deal with hard rock and metal music, which Partridge links to occulture. Rather than delivering a summary of contributions, he weaves references throughout the introduction, providing a helpful starting point for reading the book as a unified project.

Roland Boer's "Some Routine Atrocity, or, Letting the Curse of God Roar: Nick Cave and Apocalyptic" is a logical extension of Partridge's introduction. It is clear that Cave is an important figure for considering apocalyptic influences on popular music, and Boer argues that Cave is an artist with a distinctly apocalyptic worldview. Cave combines apocalyptic traditions with innovative processes to address his contemporaries through aesthetic poetics. Generally, the apocalyptic roots of his music align with ideas of God's anger, which are fundamentally related to punk sensibilities and resolve in a type of redemptive apocalypse associated particularly with women.

Mark S. Sweetnam's essay, "Evangelical Millennialism in the Lyrics of Johnny Cash," is even more specific than its title, as he explores influences of Hal Lindsey's brand of dispensationalism on Cash's lyrics. Finding Cash in a collection of this type is not surprising, and Sweetnam historicizes his music in terms of both gospel culture and specific popular dispensationalist rhetoric from the I970s and I 980 os. Sweetnam emphasizes the lack of specific doctrinal attitudes in Cash's music - the exception being Cash's treatment of apocalyptic prophecy. Influenced by apocalyptic sentiments and Cold War tensions, Cash appropriated dispensationalist prophecies for his music not in a system of theology but as representative of his own millenarianism.

In an essay titled "Metal, the End of the World, and Radical Environmentalism: Ecological Apocalypse in the Lyrics of Earth Crisis," Kennet Granholm explores the intersection of traditional apocalyptic eschatology with straight edge punk subculture-in this case, a movement associated with animal rights and ecological anxieties. Much of Granholm's essay is concerned with the importance of framing the discussion with definitions and methodological considerations. Overall, he argues that Earth Crisis's eschatology is derived from Christian apocalyptic rhetoric, but takes on new shape as it is mediated through conventions of metal music and, further, directed at pointing out impending ecological collapse.

Another name associated with hard rock and metal is Tom Morello (guitarist for Rage Against the Machine and Audioslave), but Michael J. Gilmour 
explores his solo acoustic career in the essay titled "Raging against the Machine: Tom Morello's Nightwatchman Persona and the Sound of ApocalypseInspired Schadenfreude." Morello's shift toward a solo career marked his increased engagement with social and political causes, using biblical literacy to infuse his music with calls for reform. For Morello, inherent appeals to societal upheaval in apocalyptic imagery are appropriate, and apocalyptic rhetoric "becomes a vehicle for advocacy, political posturing and social commentary" (48). Central to the ideology of Morello's Nightwatchman project, Gilmour argues, is the concept of Schadenfreude - using apocalyptic ideas to imagine the downfall of social and political enemies.

Marcus Moberg's examination of "Portrayals of the End Times, the Apocalypse, and the Last Judgment in Christian Metal Music" shifts away from secular music to consider trends in explicitly religious music. For this, Moberg uses Partridge's concept of occulture to trace developments of Christian metal from its roots in the secular genre to a type of "anti-occultural" phenomenon. Moberg adapts this framework with a nuanced view of interactions between religious and secular apocalyptic thought for evangelical musicians - who are ideologically influenced by literal biblical interpretations and popular dispensationalism in service of a project to evangelize potentially secular audiences crossing over from mainstream metal fandom.

In the essay "'When Rome Falls, Falls the World': Current 93 and Apocalyptic Folk," Sérgio Fava traces the appeal of Current 93 for young, urban audiences to the band's self-proclaimed identity as propagators of a new genre deemed "apocalyptic folk." While Current 93 is clearly dedicated to engaging with religious imagery to depict the end of the world, Fava never clearly defines "apocalyptic folk," relying mainly on the words of Current 93's front man David Tibet, who associates "folk" with audiences individually and culturally (82). Central to the concept, it appears, are certain temporal and societal elements: the futurity of eschatology, present urban anxieties, and hopes for restoration of idealized, past rural life.

Rupert Till explores the ways in which metal culture came to rest on apocalyptic associations and diabolic imagery in his essay titled "The Number of the Beast: The Adoption of Apocalyptic Imagery in Heavy Metal." He also considers headbanging as a dance form alongside the Jungian conception of "the shadow," though this is a less convincing argument. Till's most compelling ideas are in his examination of bands and personas as cultural icons of apocalyptic metal ideals, with special attention paid to Ozzy Osbourne. A major strength of this essay is the array of aspects of metal subculture an- 
alyzed: bands, audiences, album covers, lyrics, personas, even musicological considerations.

The final essay is Steven Knowles's "Who Cares? Apocalyptic Thought in Extreme's III Sides to Every Story," in which he examines Extreme's concept album as representative of "the American fascination with the idea of apocalypse" (I09). Here parallels are found with a number of previous essays, including anxieties about apocalyptic crises, historical contexts of American politics, and Christian dispensationalism. Singular to Knowles's approachand a strength for his analysis - is his focus on reception theory, drawing on fans' reactions in order to understand Extreme's connections to popular apocalyptic thought.

The relevance of Anthems of Apocalypse for reception history is apparent from its title and content as well as its place in two Sheffield Phoenix Press series focused on reception: volume 42 of The Bible in the Modern World and volume 4 of Apocalypse and Popular Culture. As part of two series concerned with the inheritance of ancient ideas in modern culture, readers might expect more explicit interactions with the long history of biblical and apocalyptic traditions. In addressing methodological frameworks, contributors account for recent examinations of apocalyptic ideas in popular culture (principally in America), though not always historical traditions behind these developments. For example, throughout the volume there is a curious lack of definitions and distinctions for apocalypse and eschatology (which are often used interchangeably) — a common quibble among scholars of early Judaism and Christianity. Further, Partridge's concept of occulture, which is adopted in various contributions, should be tempered by acknowledging that this approach addresses only one aspect within the diversity of subcultures associated with popular music. Related to the last point, there is an implicit assumption of a separation between Christian and postmodern apocalyptic thought, rather than seeing them as part of shared traditions; indeed, this is a development in other recent scholarship that should be reconsidered in light of past historical contexts. One particular exception is Granholm's essay, in which he does explicitly distinguish between apocalypse and eschatology, addresses challenging aspects of Partridge's concept of occulture, and accounts for connections between traditional apocalyptic rhetoric and modern appropriations. With such a range of scholarship in this volume, it is also disappointing that so few female voices appear: none of the contributors are female, and only passing references are made to female musicians like Sheryl Crow and Jocelyn Pook. 
The expertise of the authors ranges across a variety of disciplines, including the study of digital humanities, history, literature, media, music, the New Testament, philosophy, and religion. It is also clear that some of the contributors write as both critics and fans, most notable in certain autobiographical moments that portray how musicians have influenced the critics. The collection is made complete with the expected bibliography and index, supplemented by a discography for quick reference to specific artists and albums. As the first of its kind, Anthems of Apocalypse is worthwhile for providing a way into the subject as well as signaling avenues for future studies.

\section{Brandon W. Hawk \\ University of Connecticut}

\section{New Zealand Jesus: Social and Religious Trans- formations of an Image, I890-1940, by Geoffrey Troughton}

Bern: Peter Lang, 20II | 268 pages | ISBN: 978-3-0343I047-5 (softback) €52.10| ISBN: 978-3-035 I-0267-3 (e-book) $€ 52.10$

Books that originate in a thesis always face the issue

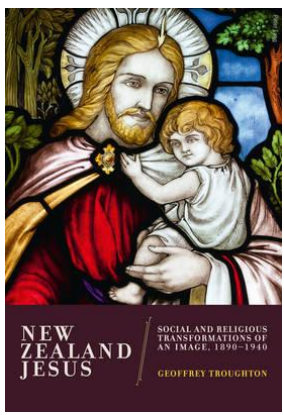
that what makes a good, solid thesis may not necessarily translate over into the subject for a good book. This is further complicated in the field of New Zealand religious history, for the market for a book on New Zealand religious history is understandably a small one. What does a book add to a thesis now easily attainable in electronic form from a university library? Of course to be published, a thesis has to be revised and in part, rewritten. But the question needed to be asked is - and this is not a personal attack but a wider question on publishing in the age of e-information-do we seek to too often publish because of the dictatorship of output managerialism? Is it better to spread out chapters of a thesis into articles for various journals that will potentially have a wider readership —or does the book, any book, still reign supreme in managerialist reviews? I know chapters of this thesis have already been published in journals. That being so, combined with the e-thesis being easily available (I found and downloaded a copy in under a minute), the question has to be: what is the point of the time and effort spent effectively rewriting 
the thesis? Is it good use of an academic's time and effort? Such are the thoughts that arose as I began to read this book.

As the author is careful to point out, this is the investigation of a particular time, place and, perhaps most importantly, culture: the Jesus-piety of colonial, primarily Protestant, Pakeha society in New Zealand, I890-1940. Maori are largely absent, excused as being "never smaller" in population than during this period, and never more separate from Pakeha society.

So this is the history of half a century of white settler Jesus-piety, a piety seeking to avoid theology and doctrine, seeking to conform rather than critique. This is therefore a history of a particular type of colonial society: a small white settler outpost, settled largely after Darwin, after Marx, a society seeking social cohesion yet with a strong undercurrent of division; a colony not a nation. Therefore the New Zealand Jesus is really a colonial settler society Jesus, a Jesus looking "home" to Britain and "across" to North America.

The book carefully discusses the differing experiences and expressions of Jesus that occurred in Pakeha settler society. This was not a Jesus of theological study and discussion, it was not an academic Jesus and it was certainly not a theological Christ, yet could be a pietistic and ecclesial Christ. It was Jesus as sentimental friend, role model, name, idol, fetish, totem, and social glue. It was Jesus as moral guide and exemplar, a Jesus used by the church and society as part of social control. As noted in the text, central to Protestant devotion was the humanity of Jesus, a humanity stressed not against his divinity but concentrated upon as the point of accessibility and meaning. This focus on the humanity of Jesus is a sign of the increasing secularization of Protestant Christianity, a shift also however into a type of good works and good morals club. This is also a colonial Jesus in that this is not a New Zealand Jesus but rather a northern hemisphere pietistic and theological Jesus taken on board down here without local adaptations and critique. This is not a cultural nationalist Jesus, a Jesus of New Zealand. Rather it demonstrates how, in many ways, it was Pakeha religion that was-and still is-the strongest and longest-running expression of the colonial mentality and longing.

Yet at the same time Jesus could be used as a claim against the institutional church - whether from the perspective of the widespread New Age or, more politically, Jesus the proto-socialist. The tension for the churches was that their role as social cohesion and the forces of conformity were in tension with an emphasis on the human Jesus as political prophet and reformer of institutions; a tension understandably most expressed in Protestant settler society. In the labour disputes of the early twentieth century was Jesus on 
the side of the workers - or the bosses? Or, as was also expressed, the Jesus of Christianity was different from the Jesus of "Churchianity."

The New Zealand Jesus was therefore increasingly used as a point of opposition to the Church. The focus on the human Jesus as opposed to the theological Christ made this much easier. A virile, manly Jesus of good works and the Golden Rule could serve as a moral everyman for a wider society still culturally Christian, if increasingly post-Christian in practice and very thin in theology. This is noted in the comment that "in many ways, New Zealand's Jesus was the children's Jesus" (I I I). A whole history of the problems of theology and church in New Zealand, including the continuing impact of the Geering controversy, the decline of the broad church, the self-removal of the liberals, and the rise of Pentecostalism and conservative evangelicalism can all be traced to this central insight. Not only was the New Zealand Jesus a children's Jesus, but there was and is a widespread shift to regard institutional Christianity as something for children and the child-like.

Of course a sentimental, child-friendly, pietistic Jesus was always going to struggle to attract the devotion, yet alone interest of men in a frontier society. Yet we must be careful to note that it is not just frontier society men who had little time for Jesus, it was industrialized, urban men as well-whether in the northern hemisphere or out in the colonies. However as noted, the manly Jesus of morality and purity was difficult to reconcile with the experiences or indeed the desires and wishes of soldiers, returned servicemen, and more widely the man of twentieth century modernity. In reading this book it appears, at least in the realms of popular piety and popular religion, that New Zealand Protestant Christianity really developed into a type of Jesus morality cult primarily for, and of, children and women. This is hinted at, yet the wider implications of this are never really fully developed.

Further, the absence of discussions on the Maori Jesus and the muted discussion of the Catholic Jesus also mean that this is only a cropped snapshot of New Zealand society and Christianity at this time. Was it worth a book? Well perhaps, but really a wider discussion including these missed areas and continuing into the present day would have been a much more valuable project. Therefore this should have been the first part of a much bigger book, for it is less than half the story. The author should be encouraged and supported to write a follow-up, expanded in scope, for that would be a fascinating and important addition to our wider socio-cultural history.

It would be interesting to see what happened to the New Zealand Jesus since 1940. A follow-up tracing the muted emergence of the Kiwi Jesus, Peter 
Matheson's Jesus of gumboots and enculturation, the romanticized Jesus of the bush, or Nigel Brown's James K. Baxter-Jesus of suburban driveways. Indeed the rise of Baxter himself as a Kiwi-Jesus avatar is a missing part of this story. For Baxter grew up in the Protestant Jesus-morality cult of Calvinism and rejected it for Catholicism, ultimately embodying the Hemi-Jesus of a still colonizing personal expression of Maori Christianity. Similarly the Jesus of Colin McCahon, first as image then as abstraction and text, also signals the challenges of enculturating Jesus in New Zealand, and within-yet againstNew Zealand modernity. Yet perhaps the most interesting Jesus to emerge was the wimpy Pasifika Jesus of bro’Town, a wimpy Jesus never measuring up to his chiefly, tattooed hyper-masculine God-father. Maybe little has changed after all ...

Mike Grimshaw

University of Canterbury

\section{Jesus in an Age of Neoliberalism: Quests, Scholar- ship and Ideology, by James G. Crossley}

BibleWorld | Sheffield: Equinox, $20 \mathrm{I} 2 \mid \mathrm{xv}+248$ pages | ISBN: 9781908-04970-4 (hardback) £60.00 | ISBN: 978-1 8446-57377-6 (softback) $£ 17.99$

One might observe that biblical scholarship is an espe-

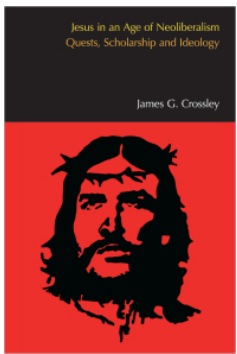
cially industrious field in which scholars have long been in spirited conversation, if not outright debate, about such weighty matters as the boundaries of the discipline, its preferred (or submerged) methods and disciplinary conversation partners, and its utility for a variety of interested audiences in the modern world. Given that biblical texts, for better or for worse, have enjoyed unusually persistent and enduring afterlives in a myriad of venues across time and cultures - inside and outside of institutional theological rhetorics, from popular music and film, to church windows and architecture, to political speeches and actions - it is no surprise that, for biblical scholars, the burden of knowledge production in a complex world, where the "object" of analysis is a moving target, can seem great. Deciding where to focus one's intellectual capacity and energy can be a daunting task, since choosing to privilege primary ancient texts, social and historical contexts and backgrounds, and/or 
histories of deployment and interpretation will yield vastly different questions and hypotheses. As Wilfred Cantwell Smith proposed more than four decades ago in his seminal Journal of the American Academy of Religion essay, "The Study of Religion and the Study of the Bible" (39 no. 2 [197I]: I 3 I-I40), a great challenge for modern biblical scholarship in a universitybased religion department-where the focus is ideally not on the teaching of religion, but teaching about religion-is to shift from unlocking the indigenous and timeless meanings of ancient scriptures to understanding how scriptures are formed, what human purposes they might serve, and what relationships we might have with scriptures in different historical and social settings: "the first point, then, is to see the Bible not merely as a set of ancient documents or even as a first- and second-century product but as a third-century and twelfth-century and nineteenth-century and contemporary agent" (I 34). Smith proposes a course of study in a religion department that would rigorously examine the roles the Bible has played, what roles it plays now, and what the future of our relationship with the Bible might look like (we might now call such an approach "reception history"). Of course, Smith finds his own curricular recommendation attractive as a relevant way forward for the study of biblical literature, and yet at the end of the essay he bemoans the unlikelihood of finding a person with doctoral training suited for such a task. Indeed, one might imagine that no one person can possibly be equipped to do justice to how biblical literature "works" in the ancient world and, perhaps more critically, beyond it. Every attempt to do so, no matter how comprehensive its claims, is partial, incomplete, and contestable.

James Crossley may agree with Smith's proposal for a shift in focus in biblical scholarship as an academic discipline, and he may even have some remedy for the question of how one is to conduct doctoral training for the massive responsibility inherent in critical biblical scholarship as it relates to the practices of teaching about religion through its reception. Where they might disagree is in where the focus of understanding and articulating our relationship with the Bible should be amplified, and where muted. Nevertheless, in Jesus in an Age of Neoliberalism: Quests, Scholarship and Ideology, Crossley suggests that we take a long and hard, even if partial and incomplete, look at how cultural and political-economic contexts shape the ideology of all academic discourses, the rhetorics of biblical scholarship more specifically, and most expressly the various contributions to the so-called "quests" for the historical Jesus along with how such debates are observed in public territory beyond ivory tower locales. This book is intended as somewhat of 
a companion, if not sequel, to his Jesus in an Age of Terror: Scholarly Projects for a New American Century (London and Oakville: Equinox, 2008); interested readers would do well to access the former book before engaging this one, as Crossley refers to it extensively as that which underlies many of the arguments presented here. Similar to Jesus in an Age of Terror, one of Crossley's aims, as stated in his introduction, is to produce a kind of intervention into scholarship that methodologically is both similar to and different from "traditional" historical criticism. In fact, Crossley explicitly states that his practice as a New Testament exegete will be especially useful in his reading of modern Jesus scholarship, so

instead of lengthy exegesis of Gospel texts, here I will exegete scholarly texts and general scholarly positions in their modern contexts. Methodologically, the sort of historical study I am pursuing here is not necessarily dramatically removed from conventional biblical scholarship; if anything, it is simply the chronology and focus of study that is different. (5-6)

To explicate his case for more fully noticing and understanding how biblical scholarship is a product of its time, and to accomplish his interpretive goals, Crossley relies on a considerable selection of scholarly resources such as his own exegetical training, Stephen Prothero's approach to locating constructions of Jesus in their cultural contexts, and critical-theoretical frameworks for understanding the political and economic structures and practices of contemporary life such as David Harvey's work on neoliberalism and Noam Chomsky and Edward Herman's "Propaganda Model" (the latter of which is a reference point throughout the book). Jesus in an Age of Neoliberalism has three subsequent parts wherein Crossley attempts to read contemporary Jesus scholarship, in its various manifestations, as (un)consciously informed by, and even a product of, neoliberal culture. Part I, "From Mount Pelerin to Eternity? Contextualizing an Age of Neoliberalism," begins with Chapter 2, "Neoliberalism and Postmodernity," where Crossley provides a brief overview of postmodernity and neoliberalism, which he states is the "broad contextual basis" (2 I) for understanding how Jesus has been constructed in modern scholarship of the last half century. In Chapter 3, "Biblioblogging: Connected Scholarship," the author extends arguments he has made elsewhere on biblioblogging: it is an important site for exploring the intersections of ideological inclinations, public performance, and scholarly 
examination. In this case, the examples for such exploration are select bibliobloggers' responses to the 201 o Haiti earthquake and the identity and politics (and identity politics) of supposedly now-defunct pseudonymous biblioblogger N.T. Wrong. Whereas Chapter 3 hones in on specific examples to make the case for how scholarship participates in neoliberal discourses, in Chapter 4, "Not Made by Great Men'? The Quest for the Individual Christ," Crossley develops a proposal that constructions of Jesus as a "Great Man" are not just inheritances of the history of scholarship, they also rather neatly cohere with neoliberal capitalist conceptions of causality and historicity, and it is this particular confluence that informs the rest of the book. The chronological period under consideration is narrowed in Chapter 5, "Never Trust a Hippy': Finding a Liberal Jesus Where You Might Not Think," wherein Crossley turns his attention to locating the various portraits of Jesus offered by proponents of the "Third Quest" such as the Jesus Seminar, attempting to show that in a neoliberal context the historical Jesus is constructed in various ways as a conveniently domesticated "Other" without the dangerous elements that usually accompany "Otherness." For Crossley, this is most obvious in studies that concentrate on "Jesus the Jew."

"Jesus the Jew" in modern biblical scholarship becomes, in Crossley's view, a signifier for a key tenet and social effect of neoliberalism: the naming and celebration of multicultural liberal identities without structural critique or change. Part II, "Jesus in an Age of Neoliberalism," contains two interrelated chapters wherein the author expounds upon this sentiment. In Chapter 6, "A 'Fundamentally Unreliable Adoration': 'Jewishness' and Multicultural Jesus," Crossley discusses the rhetorical forms and functions of constructing Jesus as Jewish in contemporary Protestant evangelical and Catholic discourses, including those recently offered by Pope Benedict XVI. This Jewish Jesus, as it turns out, is remarkably "useful" in contemporary discussions of Christianity that may themselves betray latent anti-Jewish impulses. Chapter 7, "The Jesus Who Wasn't There? Conservative Christianity, Atheism and Other Religious Influences," attends to the neoliberal aspects of discussions about the (non-)existence of Jesus in various venues that deploy the rhetoric of science and reason, from New Atheist writers such as Richard Dawkins to the recent "Jesus Project." In Part III, "Contradictions," Crossley aims to explore broader cultural and ideological issues connected to constructions of Jesus beyond, yet tangled up with, New Testament scholarship. In Chapter 8, "'Forgive Them; for They Do Not Know What They Are Doing!' Other Problems, Extremes, and the Social World of Jesus," his analysis 
extends to a particular discursive case, that of the Context Group, to illustrate a prominent feature of Chomsky and Herman's Propaganda Model: that even though individuals may purport to occupy different political space than that of the dominant ideological system, they will still, in their words and deeds, participate in, and thereby perpetuate, that very system. In the case of the Context Group (via the work of Bruce Malina), the construction of the Middle East may reduplicate Orientalist sentiments even as this runs contrary to expressions of personal pro-Palestinian politics. This analysis is extended into Chapter 9, "Red Tory Christ," wherein Crossley takes on the constructions of Jesus proffered by Radical Orthodox theologians and politicians in the UK, resulting in a Jesus that rather neatly coheres with a Radical Orthodox project that claims to speak for Christianity-a depoliticized political Jesus, as it were. Finally, in Chapter ıo, "Conclusion: They Know It and They Don't," Crossley reflects upon recent debates, including a public, online discussion concerning the introduction of faith perspectives into the Society of Biblical Literature's annual meeting, as a means to propose that more work be done to identify case studies outlining the connections between neoliberalism and New Testament studies.

Throughout Jesus in an Age of Neoliberalism, Crossley offers an array of issues to consider further, and much with which readers who inhabit many different political and theological proclivities can interact. Of course, given that there are so many topics under consideration in one volume, there is a panoply of issues with which some readers could, and probably will, take umbrage. These potential points of contention are wide-ranging: from the persistent misspelling of a prominent Marxist theorist's surname (Lukásc for Lukács), to Crossley's construction of straw men opponents and red herrings in order to make his arguments; from his off-handed use of off-therecord conversations with disciplinary colleagues, to his sometimes less-thanjudicious assessment of "traditional" scholarship; from the lack of detailed analysis of the scholars under consideration for uninitiated readers, to his rather cursory and repetitive presentation of theoretical concepts that would otherwise seem critical to flesh out for this study (most importantly, "neoliberalism"); from an insistence on framing scholarly debates in dichotomic terms, to an overuse of binary oppositions to make his points. Some scholars might also find it curious that, even as he mentions gender- and race-critical analysis briefly and in passing, Crossley's admittedly eclectic recent history of scholarship influenced by cultural contexts is one populated almost exclusively by dominant-culture-identified male New Testament scholars, which 
might prompt some to wonder just how (neo)liberal and multicultural the discipline actually is, or whether ideological criticism and Marxist analysis have intersected with gender and race in ways that might support the arguments Crossley makes. Methodologically, it is also worth noting that Crossley promises "exegesis" of scholarly texts of the recent, instead of distant, past, as part of his concentration on locating biblical scholarship as a part of the reception history of biblical texts and traditions. Yet, one might wonder what the utility is in offering "exegesis" of modern scholarship, a term that denotes a set of disciplinary practices fraught with connotations that the author himself has claimed not to fully trust, at least not when applied to ancient texts. A perhaps unintentional effect of Crossley's rhetorical construction of this project as "exegetical" is that he appears to superimpose inherent meanings and intentions onto large and disparate bodies of scholarship — meanings and intentions that only a most astute, sober reading such as his can discover. In so doing, a stability and coherence is made of Jesus studies and biblical scholarship more broadly, not to mention the cultural contexts in which this work takes place. As Crossley well knows, when using any methods to articulate the social worlds in which we might contextualize texts it is always possible, if not likely, that we are not merely describing but rather inventing the social contexts that seem most helpful in serving our aims. Clearly this observation would also apply to Crossley's own analysis, which no doubt many of his critics have already recognized. Perhaps most directly, Crossley's analysis of the constructions of Judaism among scholars of early Christianity ultimately skirts the issue that the Judaism that is constructed is relatively tame and one quite acceptable to neoliberalism (this is, in fact, where his analysis would have been most profitable). One might therefore suggest that Crossley himself does not escape this same "charge."

While some scholars might find these and other issues to be "dealbreakers," the present reviewers note several important areas where Jesus in an Age of Neoliberalism has some potential to make a positive and responsible contribution to discussions of methodology in the study of the New Testament and Early Christianity, discussions that are, we might add, vital as scholars continue to deliberate best practices for the discipline as a whole. Perhaps first and foremost is the necessity for New Testament critics to engage the history of the field, recognizing that every disciplinary question, debate, and controversy is located in space and time, and is never inoculated from ideological influences, personal and institutional politics, and power relationships. Second, New Testament scholars would do well not only to understand emer- 
gent trends in the field, but also to trace how such trends are related to (but not necessarily caused by) those of the past, as well as to assess how material realities such as geographical location and modes of communication shape knowledge production and dissemination. And third, in this work Crossley does help to make the case that New Testament scholars can deploy their considerable reading skills to examine the rhetorics of scholarship itself, in conversation with theoretical frameworks that can enhance understandings of social formation as well as the worlds in which humans are formed in relation to, perhaps even as, texts.

In addition to noting the potential to make a productive contribution to ongoing conversations in New Testament studies, we raise here several observations occasioned by our reading of Jesus in an Age of Neoliberalism that we think could benefit from further reflection, development, and argumentation. First, over the last several decades it has become common to suggest that the ideological context in which interpretation takes place will shape scholarly discourse. Less explored are the ways in which we observe how ideology shapes the methods scholars might embrace. For example, it would be worth investigating how quests for the historical Jesus are predicated not just, or simply, on the predilections of interpreters embedded in their contexts, but on ways those contexts might participate in the organization of knowledge. Perhaps some additional attention to the emergence of the empirical category "history" as a scientific discourse that provides certainty as to "facts" and "story" and "existence" would further illuminate this point. Further, in terms of how modes of organizing knowledge and communicating scholarly discourses operate in a neoliberal context, it is clear that biblioblogging is a well-established media form. However, a more nuanced understanding of biblical scholarship in an age of neoliberalism might view the uses of biblioblogging and social media as a means to participate in the commodification of the biblical scholar as a persona, or "personal brand," as well as examine how blogs have become a form of advertising for certain ideas and individual personalities as "products" in an online marketplace, which is not devoid of its own economic structure. In a neoliberal context, the "marketplace of ideas" is perhaps heavy on the "marketplace," less so on the "ideas." Moreover, it is clear that the individual—person or corporation-is emphasized and valorized in neoliberalism. A more trenchant consideration of quests for the historical Jesus in light of the rise of the individual as a discrete entity in an age of neoliberalism might foreground the role of personal consumption in identity formation under neoliberalism - in this light, we 
would do better to analyze the ways and means by which we construct Jesus to render him palatable for mass production and consumption in our current neoliberal landscape, including the role that social media might play in this phenomenon. While Crossley rightly suggests that his work is partial and that many more examples of biblical scholarship's involvement with neoliberalism need to be located and explored, we submit that further work in this area will benefit from clarity about the difference this kind of analysis can make to the field as a whole, as well as what is at stake, and why it matters.

Finally, we add that Crossley's Jesus in an Age of Neoliberalism has inspired us to think a great deal about the current state of scholarship, social media, and the future of the discipline. There is obviously much more to say on all of this. As a last word in this review, we note that without the persistent impact of neoliberalism on the contemporary social and economic global scene, Crossley's own book-and persona(lity), in print and in social media-would not likely resonate as it does with us now. And that obviously provides food for further thought. To be sure, Crossley has shot the first volleys over the proverbial disciplinary "bow" (and there are no real casualtiesfor which some will breathe a sigh of relief and others of regret). We await the scholarship that follows, and that Jesus in an Age of Neoliberalism in fact demands, which will both evaluate and also flesh out, not to mention more fully cook, the smorgasbord of raw ideas that Crossley has laid on our plates.

\section{Davina C. Lopez Todd Penner Eckerd College Austin College}

\section{Dreaming of Eden: American Religion and Politics in a Wired World, by Susan Brooks Thistlethwaite}

New York: Palgrave Macmillan, 20 Io | xi + 220 pages | ISBN: 978-0-230-10780-9 (hardback) \$39.00

Susan Thistlethwaite is a highly respected professor of theology and former president of Chicago Theological

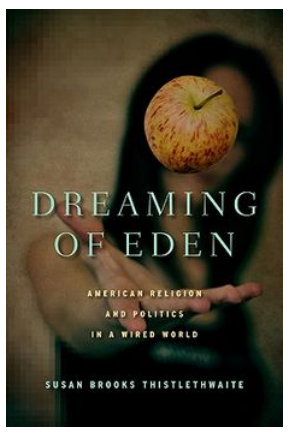
Seminary, who has worked as a bible translator and has written extensively on environmental and ethical issues. This book seems to have originated in essays contributed to her weekly column in The Washington Post online. It 
is clearly directed as a popular market and takes the theme of the Garden of Eden in order to explain why Americans are often so politically naïve and get themselves into such awkward situations. It is classified as a work of public theology, and is full of entertaining insights about the ways in which theological beliefs shape Americans' perception of the world.

There are nine chapters, two in Part I on "Dreaming of Eden," which explore the themes of "Adam, Even and the Garden" and "Citizens Cain and Abel." In the first, links are made between the movie The Passion of the Christ and Eden, and then the movie Pleasantville, to make the theme of Americans' loss of innocence, while in the second the links between civilization and destruction are explored as the industrial revolution and the cyber revolution reinterpreted. Part 2 is entitled "The Danger of Innocence" and begins with a chapter on "Iraq and Torture," which analyses American involvement in Iraq and the Left Behind novels as well as other aspects of the politics of 9/II. Chapter 4 covers the financial meltdown, the American devotion to excess and how conservative Christianity helped to cause all this. There is again a range of movie illustrations. Chapter 5 is on creation and climate change, and includes an account of a visit to the Creation Museum and the attitudes of liberal and conservative Christians to climate change. Part 3 is entitled "A Better Story" and includes a chapter, "The Practice of Goodness" which is devoted to the theme of the virtues of comedy. The following chapter is on national security, and includes discussion of Planet of the Apes and J. K. Rowling. The next chapter is entitled "God Doesn't Run Markets, People Do" and challenges the notion that the market is always right. The final chapter is on the Millennials, and explores the movie The Matrix.

The themes include (but despite the title, are not dominated by) the internet, starting with the symbol of Apple computers, the stock market, national security, environmentalism, the Iraq war, and administration politics. While these themes are a little dated now, one can certainly appreciate the witty way in which this book portrays the quest for innocence, and the failure to realise that none of us are unaffected by the fallenness of humanity. But as you may gather I found the blend of movie interpretation and public theology a little superficial. Perhaps the problem was that I had not seen all the movies mentioned, or did not see them as particularly significant. I would much rather have read Thistlethwaite writing a sustained argument than a book produced on demand, I suspect, for a literary agent.

There is a rather high level of assertion and polemic in the book which frustrated me; in particular the tendency to hold evangelicals especially be- 
lievers in the rapture, creation, and the chosen destiny of America responsible for many of today's ills. Doubtless there is much truth in the statements, but the polemic I found irritating. The gems of the book are the entertaining accounts of the ways in which "the passion of the Christ" is actually about the garden of Eden, the puns and parallels of the story of Cain and Abel, and the self-confession of the way in which peace advocates can themselves end up as believers in an innocence which no-one can afford. But it is an expensive price to read such gems.

Peter Lineham

Massey University

\section{The Book of Mormon: A Biography, by Paul C. Gutjahr}

Lives of Great Religious Books | Princeton: Princeton University Press, 20I 2 | xix+255 pages | ISBN: 978-0-69I-I4480-I (hardback) $\$ 24.95$

This is a really delightful book which forms part of a new series by Princeton on the Lives of Great Religious Books, which has already included publications on the Tibetan Book of the Dead, Bonhoeffer's Letters

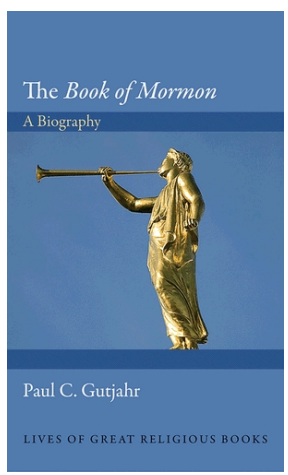
and Papers from Prison (by Martin Marty), the I Ching, and Augustine's Confessions. Projected volumes seem to treat individual books of the Bible and I see that Bruce Chilton will write on the Book of Revelation, while others have been commissioned on the Dead Sea Scrolls, C. S. Lewis's Mere Christianity, and the Book of Common Prayer, as well as a range of texts from other world religions.

It is not immediately apparent that a book has a life history-does a book grow old? But books certainly do have histories, and in an age which seems inclined to abandon printed publications it is valuable to realise how much cultural history is bound up in these works. Gutjahr's work is essentially a cultural history of Mormonism, although from a rather narrow angle. The book carefully eschews all the vast debates that have raged around the volume and it is not immediately clear from the volume whether the author is a member of the Latter-day Saints or not-although the neutral tone might 
suggest that he is not, and the previous publications of this professor of English at Indiana University include studies of Charles Hodge, and a history of the Bible in nineteenth-century America. But literature on the Mormons has often been polemical, and much of the really good historical study has come from Mormon scholars, although they are often somewhat estranged from the institutions of the church.

The book is written around the motif of the life of a tree, not a human, and falls into three parts, "Germination," "Budding" and "Flowering." So this is a book about the appearance of the Book of Mormon as it appeared to the onlooker. There is much in the book about changing texts, and Mormons do allow that their current prophet can order fiat changes in the text-which is essential because there are no originals to go back to. There is very little about the order and content of the Book of Mormon. A particularly interesting aspect of the book is the author's claim that many Mormons were until recently much better acquainted with the Bible than with the Book of Mormon, and that only in recent years have there been strong injunctions within the church to read it. Certainly my first copy of the Book of Mormon had handwritten notes placed there by a missionary training, going through a tiny catena of texts which were designed to show that the book was selfvalidating, and using arguments based on the testimonies in the front of the book by the witnesses who had seen-or nearly seen — the golden plates, as well as references in the Old Testament which bolstered the claim to a third testament. In this sense the Book of Mormon was a long and complex tale, as Gutjahr notes, of alleged tribal histories and the details of the characters are somewhat complex and tedious. At this point I must confess to a certain surprise that Gutjahr did not treat us to a literary analysis of a book which is difficult to read simply because of its clumsy attempt at Jacobean English and (at least in the traditional text) presented verse by verse rather than in paragraphs.

However rather than lament what was not written, I must express delight in the tone of this book which lays a platform for scholarship about the Latter-day Saints which is about their central text but is not polemical. Gutjahr argues that this book is surely one of the great achievements of American culture, and he traces the growth in publication of the text so that I 50 million copies have been distributed in a vast array of languages, following a very conservative principle of interpretation. The Latter-day Saints are a text-based religion. There is no mention in this volume of the Maori translation, but it has a colourful history of its own, with the first translation (later recognised 
as rather clumsy) supposedly produced in near miraculous circumstances of its own. But my own research suggests that Maori Mormons held one or two key values about a new revelation, but talked little about the content of the book. So this bears out Gutjahr's interpretation.

Gutjahr's account of the writing (or translation) of the book of Mormon carefully picks its way through the various controversial interpretations of these circumstances. He notes that from the earliest days there were essentially three interpretations of the circumstances of the writing of the book, the supernaturalist approach which believed that this was a new divine revelation, the plagiarist view that emphasised sources which they believed Smith had used, and the naturalist school which emphasised Joseph Smith's fertile imagination. The middle school might well have received more attention from a literary critic than we find here, but the author places his focus on the changes in the editions of the Book of Mormon from its first edition in I 830 to the 1840 edition and a range of different books, although none formally advocated polygamy despite evidence that it was practised from about I 84I. For Mormons the changing requirements of other texts were perhaps more influential. One particular interest of this book is that it highlights what happened to the so-called "Reorganised Church" (or RLDS) which continued to be led by a descendant of Joseph Smith, and now seems to have abandoned any literal reading of the Book of Mormon. Meanwhile the increasingly institutionalised Utah-based church has become more and more systematic in its translation and distribution of the sacred text, and shows no signs of regarding it in a metaphorical light. The work of Hugh Nibley in attempting to verify the Book of Mormon from Middle Eastern sources, and the work of John Sorenson to locate it in Central America are striking examples of this very literal approach to the text, although so far they have yielded no fruits. Meanwhile illustrated editions have fixed images of the events of the book, and these are quite familiar in the way the Book of Mormon is promoted in New Zealand and the Pacific.

As I was writing this review news came that the Broadway musical on the Book of Mormon which the author discusses in his final chapter has arrived in London's West End. The Mormons in unusually magnanimous spirit have advertised their Book in the show's programme. I did find the lack of theological engagement with this generation of Latter-day Saints a disappointment, as in my experience, some of the eager searches for archaeological evidence for the Book of Mormon are regarded with some amusement by informed Mormons, and the author says nothing about the controversy of the I 980 os 
over the forged Salamander letters in which the Church of Jesus Christ of Latter-day Saints seemed to be alarmed and anxious to suppress what turned out to be false allegations about letters by Joseph Smith suggesting that he was interested in magical practices.

So this is a fascinating read, if frustrating at times. It is also an a charming little book, in a neat octavo size, only issued in hardback, on fine paper, with maybe thirty fine black and white illustrations. It was in every sense a pleasure to read.

Peter Lineham

Massey University 